NBER WORKING PAPER SERIES

\title{
THE LIMITATIONS OF STOCK MARKET EFFICIENCY: PRICE INFORMATIVENESS AND CEO TURNOVER
}

\author{
Gary B. Gorton \\ Lixin Huang \\ Qiang Kang \\ Working Paper 14944 \\ http://www.nber.org/papers/w14944 \\ NATIONAL BUREAU OF ECONOMIC RESEARCH \\ 1050 Massachusetts Avenue \\ Cambridge, MA 02138
}

May 2009

We appreciate comments and suggestions from seminar participants at Georgia State University, University of Miami, and University of North Carolina at Charlotte. We thank Stephen Brown for sharing his quarterly PIN estimates and Dirk Jenter for sharing the CEO turnover data, developed by Jenter and Kanaan (2006). We also thank Bunyamin Onal for research assistance. The views expressed herein are those of the author(s) and do not necessarily reflect the views of the National Bureau of Economic Research.

NBER working papers are circulated for discussion and comment purposes. They have not been peerreviewed or been subject to the review by the NBER Board of Directors that accompanies official NBER publications.

(C) 2009 by Gary B. Gorton, Lixin Huang, and Qiang Kang. All rights reserved. Short sections of text, not to exceed two paragraphs, may be quoted without explicit permission provided that full credit, including $(\odot$ notice, is given to the source. 
The Limitations of Stock Market Efficiency: Price Informativeness and CEO Turnover

Gary B. Gorton, Lixin Huang, and Qiang Kang

NBER Working Paper No. 14944

May 2009

JEL No. G0,G1,G14,G3

\begin{abstract}
$\underline{\text { ABSTRACT }}$
Stock prices are more informative when the information has less social value. Speculators with limited resources making costly (private) information production decisions must decide to produce information about some firms and not others. We show that producing and trading on private information is most profitable in the stocks of firms with poor corporate governance - precisely because it will not be acted upon - and less profitable at firms with better corporate governance. To the extent that the information in the stock price is used for disciplining the CEO by the board of directors, the informed trader has a reduced incentive to produce the information in the first place. We test our model using the probability of informed trading (PIN) and the probability of forced CEO turnover in a simultaneous-equation system. The empirical results support the model predictions. Stock prices are efficient, but there is a limit to the disciplining role they can fulfill. We apply the model to evaluate the effects of the Sarbanes-Oxley Act of 2002.
\end{abstract}

Gary B. Gorton

Yale School of Management

135 Prospect Street

P.O. Box 208200

New Haven, CT 06520-8200

and NBER

Gary.Gorton@yale.edu

Lixin Huang

J. Mack Robinson College of Business

Georgia State University

Atlanta, GA 30303

lxhuang@gsu.edu
Qiang Kang

School of Business

University of Miami

Coral Gables, FL 33124-6552

q.kang@miami.edu 


\section{Introduction}

Stock prices are more informative when the information they contain has less social value. We show that there is a fundamental tension between the informativeness of stock prices and the effectiveness of corporate governance, which limits the disciplining role of stock prices. Speculators with limited resources cannot become privately informed about every firm; they choose to become informed about firms where the information will not affect corporate decisions. We study these issues in the context of CEO turnover. Monitoring and possibly removing the CEO is the most important function of a board of directors of a corporation. Boards of directors rely on stock prices as one source of information for monitoring CEO performance. But, we show that speculators prefer to become informed about firms with poor corporate governance rather than about well-run companies, ceteris paribus. Paradoxically, the stock prices that are most informative are that way precisely because the information will not be acted upon, and therefore has no social value.

In order to effectively monitor the $\mathrm{CEO}$, the board of directors needs accurate information to judge whether or not the $\mathrm{CEO}$ is performing. If the $\mathrm{CEO}$ is not performing, then the board needs to remove the CEO, which is costly to do. We show that the informativeness of the stock price is lower to the extent that the board will react to the information in the stock price. If the board of directors reacts to the stock price promptly and effectively, their action destroys the value of the informed trader's private information and discourages him from producing information in the first place. Firms with more heavily entrenched managements have poorer corporate governance, but relatively more informative stock prices. But, this information plays little disciplining role.

The intuition for our main result is this. A speculator thinking of producing information about a firm, can profitably trade on the information if he produces a private signal at a cost about the quality of the CEO, because that is information about future cash flows. Suppose he finds that the CEO is of low quality; he sells the stock (possibly he short sells), causing the stock price to go down because the market maker who sets the price knows there may be informed trades. The board of directors observes that the stock price goes down, and infers that the current CEO is a bad type and replaces him with a new CEO. In this case, the stock price increases, rather than declining in favor of the informed trader, because the market maker anticipates how the board will respond. The informed trader loses money because firm value does not go down as he had expected. Anticipating that the board will act in this way, the informed trader chooses not to produce information about this firm. But, if the informed trader does not trade on privately produced information, it is not reflected in the price and the board may not know whether to replace the CEO. In other words, although the board's efforts depend on the informed trader's information production, the informed trader's effort to collect information depends on the board not using the information. We first present a simple model to illustrate this intuition and 
then focus on the tests of this prediction.

The bulk of the paper is empirical analysis. Our empirical analysis consists of both reduced-form and structural estimation of the theoretical predictions of the model. In particular, the simultaneousequation estimation aims to capture the interaction between the decisions of the informed traders and the decisions of the boards of directors. The analysis proceeds in three steps. Reduced-form tests impose the least structure, examining the effect of CEO entrenchment on informed trading and CEO turnover by putting the endogeneity problem aside. We find that informed trading is increasing in CEO entrenchment and CEO turnover is decreasing on CEO entrenchment. The partial-information and full-information structural tests impose the endogeneity of informed trading and CEO turnover. Again, the empirical results confirm our model predictions. That is, we find that informed trading is decreasing in the board's monitoring effort; in contrast, the board's optimal monitoring effort is increasing in informed trading.

Our paper is related to a number of literatures. There is a theoretical literature that studies the impact of informative stock prices on corporate decisions. In this literature, information in stock prices has social value because it affects corporate decisions. This is called the "feedback" effect. Examples include Fishman and Hagerty (1992), Leland (1992), Holmström and Tirole (1993), Khanna, Slezak, and Bradley (1994), Dow and Gorton (1997), Subrahmanyam and Titman (1999), and Dow and Rahi (2003). The theoretical part of our paper is most closely related to Dow, Goldstein, and Guembel (2007), who independently find a feedback effect of stock prices on firm decisions. As in our model, informed traders will not produce information if, based on that information, firms - in their case -cancel investment projects. They argue that overinvestment is sometimes necessary to induce speculators to produce information. Our paper differs in that we focus on the effect of the underlying corporate governance structure on equilibrium price informativeness and the likelihood of CEO turnover. By focusing on CEO replacement rather than investment, we produce a structural model that can be empirically tested with the CEO turnover data.

There is also a related empirical literature on the feedback effect of stock prices, though it is not always thought of as the board or the CEO learning from stock prices. Most closely related to our work is that of Chen, Goldstein, and Jiang (2007) who study this feedback effect empirically, showing that measures of informed trading have a positive effect on corporate investment. Our paper is very different because we estimate the simultaneous system jointly determining the informativeness of stock prices and the corporate decision, in our case the CEO replacement. Other, but more distantly related, examples include Baker, Stein, and Wurgler (2003), Luo (2005) and Bakke and Whited (2008), among others. 
Finally, there is a large literature on CEO turnover. Examples include Kaplan and Minton (2006) and Jenter and Kanaan (2006) who show that firm performance, as measured by stock returns, plays a very important role in affecting CEO turnovers. Huson, Parrino, and Starks (2001) find that the relation between the likelihood of forced CEO turnover and firm performance, as measured by stock returns, has not changed significantly over the period 1971 - 1994, despite substantial changes in governance mechanisms. These findings confirm the role of the stock market. If firms rely on market information to make replacement decisions, then how much information is contained in the stock price is an important issue. Relative to this literature, our contribution is to analyze the determinants of the informativeness of the stock price. To our knowledge, we are the first to analyze the interaction between the informativeness of the stock price and the CEO replacement decision, by treating the two variables as endogenous in a simultaneous-equations model.

The paper proceeds as follows. In Section 2 we first describe the model setup and the basic assumptions. We characterize the board of director's optimal disciplining policy of the firm's CEO, based on inference from the stock price. The stock price is informative because of private information impounded in the price via private costly information production. So, we also characterize the informed trader's optimal information effort. We solve the two optimization problems independently, finding the best response function of the board by taking the informed trader's action as exogenously given, and vice versa. Afterwards, we solve for the simultaneous decisions in a Nash Equilibrium. In Section 3 we derive empirical implications, put forward testable hypotheses, and explain the empirical strategy. In Section 4 we first present the data sets that we use, and summarize them. The subsequent subsections present the empirical results, in three steps. We first test straightforward reduced-form models. While these do not take advantage of the simultaneity of the decisions, they provide a first test that is free of the endogeneity problem. Then we test structural models of the simultaneous equations for the two endogenous variables. We look at two methods for testing the simultaneous system. The first is a partial information method, and the second is a full-information Generalized Least Squares approach. In Section 5 we explore another application of the model predictions, with regard to passage of the Sarbanes-Oxley Act of 2002 (SOX), which sought to improve corporate governance. We examine whether the informativeness of stock prices and CEO turnover are negatively related, and how this relationship changes in response to the passage of SOX. As a by-product, the analysis provides evidence on whether SOX has been effective in meeting its stated goals of reducing entrenchment. Section 6 concludes. 


\section{The Model}

In this section we present a simple model of the interaction between private information production, trading, stock price informativeness, and corporate governance, focusing on the decision of the board of directors to replace the CEO.

\subsection{Model Set-up and Results}

We consider a publicly-traded firm that operates in a risk-neutral economy where the interest rate is normalized to zero. There are two periods and three dates, date 0,1 , and 2. Agents in the economy include a CEO hired to run the firm (and who is possibly replaced with another CEO later), a board of directors which monitors the $\mathrm{CEO}$, an informed trader who produces private information about the firm's earnings and trades on the information, a market maker who sets the price in the stock market, and liquidity traders.

The firm's investment project requires inputs of both human and physical capital. The return to the investment depends on the quality of the human capital, in particular, the CEO. If a "good" CEO is hired, the investment generates a high return, which we normalize to 1. If a "bad" CEO is hired, the investment generates a low return, which we normalize to zero. There is uncertainty about the CEO's quality. At date 0 , when a CEO is hired, it is only known that with probability $m$ he is a good CEO; with probability $1-m$ he is a bad CEO. (CEOs do not know their type, so there is no signaling or screening in the model.) The board has a chance to replace the CEO at date 1 . With the elapse of time the board may get some information about the quality of the new CEO, and come to learn what type of CEO is needed. Consequently, we assume that unconditionally any new CEO hired at date 1 is better than the old CEO. That is, the new CEO has quality $r>m$, so he is a good CEO with probability $r$ and a bad CEO with probability $1-r$. We make the assumption that $r>m$ just for simplifying exposition. So long as the firm has a chance to find a new CEO at the interim date who has quality better than $m$, our results hold. What matters is that the informed trader's information is less valuable when the incumbent CEO is replaced, even if that only occurs with a small probability.

The firm's stock is traded in the secondary stock market. This provides an opportunity for the informed trader to make a profit on his private information. The prices of shares at the three dates are $p_{0}, p_{1}, p_{2}$. At date $2, p_{2}$ is just the final realized cash flow. The key variable is the interim stock price at date $1, p_{l}$. The interim price $p_{l}$ not only contains the informed trader's private information about the quality of the incumbent manager; it also incorporates the market's expectation about the board's reaction to this information with respect to managerial replacement. 
The information about the incumbent CEO only comes from the informed trader. ${ }^{1}$ At date 1 , the informed trader has a chance to learn the quality of the incumbent CEO at a cost. How accurate the information is depends on the cost incurred. We assume that the informed trader learns whether the incumbent CEO is good or bad with probability $\theta$ at a cost $A \theta^{2} / 2$, with $A>0$. The informed trader needs to decide how much information he produces; in other words, $\theta$ is the informed trader's decision variable.

The informed trader's information becomes embedded in the stock price through his trading. We borrow the market structure of Kyle (1985) to determine the stock price in equilibrium. Specifically, we assume that the informed trader and the liquidity traders submit orders to the market maker who sets the share price conditional on the order flow that he observes. The liquidity traders submit either a buy order or a sell order of size $\delta$ with equal probability. The informed trader submits an order contingent on the information he has received. If he receives good news (that the incumbent CEO is "good"), he submits a buy order; if he receives bad news, he submits a sell order; he does not trade if he receives no news. In order to hide his order behind those from the liquidity traders, the informed trader always submits an order of size $\delta$ whenever he trades. The market maker can only observe the aggregate order flow; he cannot tell the identity of the agent submitting the order. Upon receiving the orders, the market maker sets the price equal to the expected value of the firm contingent on two things: first, the information he infers from the order flow; second, his conjecture of the board's reaction to the stock price, given the firm's governance regime (which is common knowledge).

On the equilibrium path, the market maker will observe one of five possible order flows: (1) two buy orders; (2) two sell orders; (3) one buy order and one sell order; (4) one buy order; and (5) one sell order. If he observes two buy orders, he knows that the informed trader has submitted a buy order and he infers that the incumbent CEO is a good one. Since there is no reason to replace a good CEO, the market maker sets the stock price equal to one. If the market maker receives two sell orders, he knows that the informed trader has submitted a sell order and infers that the incumbent CEO is bad. In all other cases, the aggregate order does not reveal the informed trader's information, and the market maker only knows that the incumbent is of quality $m$.

When the market reveals that the incumbent CEO is not a good manager, it is in the board of directors' interest to replace him because a new CEO generates a high return with a higher probability. But, a replacement is costly and uncertain. As briefly reviewed below, boards are complicated and they

\footnotetext{
${ }^{1}$ The board of directors or block shareholders could also produce information, but for simplicity we do not model these sources. We assume that the stock market provides external information that is useful, in addition to internal information, for making CEO replacement decisions.
} 
cannot always agree. We assume that in order to make a successful replacement with probability $\gamma$, the board has to incur a cost $E \gamma^{2} / 2$. The parameter $\gamma$ will be chosen by the board given that the board faces a CEO who is entrenched to some extent. The parameter $E$ reflects how difficult it is to remove a manager, and we interpret it as a measure of the extent of managerial entrenchment. The choice of $\gamma$, and hence incurrence of the cost, occurs before the market reveals information about the incumbent manager. ${ }^{2}$ We treat the replacement cost as a cost privately borne by the board members, for example, as the stigma of being on the board of a company that has not removed a bad $\mathrm{CEO}^{3}$ If the cost were to be an explicit cost to the firm, then it would have to be reflected in the share prices, which could be modeled, but for simplicity we have not done this. This is discussed further below.

When the market maker infers from the order flow that the incumbent CEO is not a good type, he rationally anticipates that the board will replace the CEO with probability $\gamma$ and he incorporates this expectation into the stock price he sets. The market maker sets the stock price equal to $\gamma r$ if he receives two sell orders and the aggregate order reveals that the CEO is bad. He sets the price equal to $m(1-\gamma)+r \gamma=m+(r-m) \gamma$ if he receives one buy order, or one sell order, or one buy order plus one sell order. In all these three cases, the aggregate order flow does not reveal the manager's type.

The following table shows the possible order flows, the expected stock prices, and the board's reaction at date 1 .

\footnotetext{
${ }^{2}$ By assuming that the board of directors makes the monitoring effort before observing the stock price, we make the analysis simple because otherwise the board's decision would be contingent on the stock price. However, the main results are still valid even in the case that the board makes the decision after observing the stock price.

${ }^{3}$ Directors seem concerned about their reputations, as a strong reputation aids in getting more board seats. Fich (2005) finds that the cumulative abnormal return is significantly greater upon announcement of the addition of a director who is CEO of another firm with a higher industry-adjusted ROA. Fich and Shivdasani (2007) find that directors who sit on the boards of firms that are the subject of shareholder class-action lawsuits alleging financial fraud see a significant drop in the number of seats they hold. Also, see Gilson (1990) and Kaplan and Reishus (1990).
} 


\section{Summary of the Outcomes}

\begin{tabular}{|c|c|c|c|c|c|}
\hline News & $\begin{array}{c}\text { Order Flow in } \\
\text { the Stock } \\
\text { Market }\end{array}$ & $\begin{array}{c}\text { Probability } \\
\text { of Event }\end{array}$ & Stock Price & Board Reaction & $\begin{array}{c}\text { Informed } \\
\text { Trader's } \\
\text { Expected } \\
\text { Firm Value }\end{array}$ \\
\hline Good & 2 Buys & $m \theta / 2$ & 1 & Retain & 1 \\
\hline Good & 1 Buy and 1 Sell & $m \theta / 2$ & $m+(r-m) \gamma$ & Replace with prob $\gamma$ & $1-(1-r) \gamma$ \\
\hline Bad & 2 Sells & $(1-m) \theta / 2$ & $r r$ & Replace with prob $\gamma$ & $\gamma r$ \\
\hline Bad & 1 buy and 1 sell & $(1-m) \theta / 2$ & $m+(r-m) \gamma$ & Replace with prob $\gamma$ & $\gamma r$ \\
\hline None & 1 buy or 1 sell & $1-\theta$ & $m+(r-m) \gamma$ & Replace with prob $\gamma$ & $m+(r-m) \gamma$ \\
\hline
\end{tabular}

Now we turn to calculating how much profit the informed trader expects to make in each case. If the interim stock price is not equal to 1 , the board of directors knows that "the market" did not identify the incumbent CEO as "good" and tries to replace the CEO. If the CEO is replaced, there is no uncertainty about the return on the investment; it is $r$. In this case the informed trader's information is no longer useful. This is the main force in our model that creates the tension between information production, so that prices are informative, and corporate governance. On the one hand, the CEO replacement decision depends on the information the informed trader injects into the stock price via trading; on the other hand, CEO replacement changes the future cash flow and eliminates the value of the informed trader's private information. The informed trader can profit from his private information only if the stock price does not reveal his information and if the CEO is not replaced. If good information is not revealed, his profit is $\delta(1-m)(1-\gamma)$, which is equal to the difference between the informed trader's expected firm value and the interim stock price (see the second row in the table); this happens with probability $m \theta / 2$. If bad news is not revealed, then the speculator's profit is $\delta m(1-\gamma)$ (see the fourth row in the table); this happens with probability (1-m) $\theta / 2$. In equilibrium, the informed trader takes the board's choice of $\gamma$ as given and chooses how much information to collect. His decision variable is $\theta$, the effort he makes to collect information, which is also the probability that he receives information (good or bad).

The informed trader's optimal effort choice, $\theta$, solves:

$$
\operatorname{Max}_{\theta} \quad \frac{1}{2} \delta m \theta(1-m)(1-\gamma)+\frac{1}{2} \delta(1-m) \theta(m-0)(1-\gamma)-\frac{1}{2} A \theta^{2}
$$

The objective function is quadratic and the optimal solution is:

$$
\theta=\Gamma(1-\gamma)
$$


where $\Gamma \equiv \frac{\delta m(1-m)}{A}$

The solution says that the informed trader's effort decreases with the probability that the board replaces the incumbent manager. In case a replacement happens, the firm's cash flow depends on the new CEO's quality, and the informed trader's information about the old CEO is no longer useful. In other words, monitoring by the board impairs the profitability of information production by the informed trader. In equilibrium, the informed trader's choice also has an impact on the board's choice of replacement probability. Before we solve these two choices jointly, we look at the board's decision, taking the informed trader's effort choice as exogenously given.

The board wants to replace the CEO when the market reveals that he is the bad type. When a bad CEO is replaced, the payoff of replacement is $r-0$; the probability of a bad CEO being revealed is (1- $m) \theta / 2$. When a CEO of type $m$ is replaced, the payoff to replacement is $r-m$, and the probability of the market price being uninformative is $1-\theta / 2$. Since replacement only succeeds with probability $\gamma$, the board's objective function is:

$$
\operatorname{Max\gamma } \quad \gamma\left[\frac{1}{2}(1-m) \theta(r-0)+\left(1-\frac{1}{2} \theta\right)(r-m)\right]-\frac{1}{2} E \gamma^{2}
$$

The optimal solution is:

$$
\gamma=\frac{2(r-m)+m \theta(1-r)}{2 E}
$$

The board is not perfect in its ability to discipline the CEO. As we discuss below, the board itself might well be conflicted. Here this is modeled by the exogenous parameter $E$, which characterizes the extent of the CEO's entrenchment. The optimal solution shows that the board is less able to discipline the CEO, to the extent that the CEO is entrenched, i.e., $E$ is higher. We can also see from the board's optimal decision, that the board's monitoring choice increases with the informativeness of the stock price. When the informed trader makes a greater effort to acquire information, it is more likely for the market to reveal a CEO who is not good and thus needs to be replaced. Therefore the board can replace the incumbent CEO more accurately and the payoff to the board's effort is larger.

We summarize the informed trader's and the board's best response decisions with the following proposition. 
Proposition 1: Taking the board's monitoring effort, $\gamma$, as given, the informed trader's optimal information production effort is $\theta=\Gamma(1-\gamma)$, which is decreasing in $\gamma$. Taking the informed trader's information production effort, $\theta$, as given, and the board's optimal monitoring effort is $\gamma=\frac{2(r-m)+m \theta(1-r)}{2 E}$, which is increasing in $\theta$.

The proposition makes the point that the informativeness of share prices, which depends on $\theta$, is limited by the extent to which the price is used to affect the subject of the informed trader's speculation, namely, the CEO. Although the board wants to act on more accurate information extracted from the stock price, to the extent that the board is effective in replacing the CEO, the informed trader has a greater disincentive to collect information. The tension caused by the interaction between the board of directors and the informed trader determines how informative the stock price is and how likely a manager is to be replaced.

Next we solve for the equilibrium choice of $\gamma$ and $\theta$ jointly in a Nash Equilibrium. From equations (1) and (2) we derive the optimal solutions for $\gamma$ and $\theta$ as follows:

$$
\begin{aligned}
\gamma & =\frac{2(r-m)+m(1-r) \Gamma}{2 E+m(1-r) \Gamma}, \quad \text { and } \\
\theta & =\frac{2 \Gamma[E-(r-m)]}{2 E+m(1-r) \Gamma}
\end{aligned}
$$

The solution for $\gamma$ shows that the board's optimal effort choice is decreasing in the degree of entrenchment, $E$. How the informed trader's information choice $\theta$ is affected by entrenchment is less clear. Intuitively, entrenchment only affects the informed trader's choice of $\theta$ through the board's effort choice $\gamma$. Since $\theta$ is decreasing in $\gamma$, we conjecture that $\theta$ is increasing in entrenchment, $E$. Taking the derivative of $\theta$ with respect to $E$, we get:

$$
\frac{\partial \theta}{\partial E}=\frac{\left.2 m(1-r) \Gamma^{2}+4(r-m)\right]}{[2 E+m(1-r) \Gamma]^{2}}>0,
$$

which confirms the conjecture.

Proposition 2: When the board's monitoring effort choice, $\gamma$, and the informed trader's optimal information choice, $\theta$, are jointly endogenized in equilibrium, we have $\gamma=\frac{2(r-m)+m(1-r) \Gamma}{2 E+m(1-r) \Gamma}$ and $\theta=\frac{2 \Gamma[E-(r-m)]}{2 E+m(1-r) \Gamma}$, with $\gamma$ decreasing in $E$ and $\theta$ increasing in $E$. 
Proposition 2 expresses the outcome in terms of the degree of entrenchment, $E$. From the informed trader's point of view, a more entrenched CEO offers a higher expected return on information production because this CEO is not likely to be ousted by the board in case there is bad news in the stock price. From the point of view of the board of directors, it is increasingly costly to discipline a CEO who is entrenched. And, ironically, entrenched CEOs are associated with more informative stock prices.

\subsection{Discussion of the Model}

The model assigns a central role to the board of directors, which itself is endogenously chosen (e.g., see Hermalin and Weisbach 1998, 2003 and Adams and Ferreira 2007). The board members may be chosen by the CEO and there may be few independent directors. Further, the CEO may be chairman of the board. Bebchuk, Fried, and Walker (2002) argue that the CEO essentially controls the board. Ryan and Wiggins (2004) argue that independent directors are more capable of resisting this control. They find, for example, that firms with more inside directors, entrenched CEOs, and CEOs who are also chairman of the board, are less likely to use equity-based compensation. There is a very large literature on these issues. We have modeled the possibly conflicted board by making the board imperfect. It cannot discipline perfectly even when it has perfect information that the CEO is bad. It can only fire the CEO with probability $\gamma$ and that depends on the extent of entrenchment, $E$, and on the informativeness of the stock market. In our empirical work we will take into account proxies of $E$ from both the CEO's perspective and the board's perspective.

In order to effectively monitor the CEO, the board needs accurate information to judge whether or not the CEO is performing; second, the board needs the power to discipline the CEO. Unfortunately, our model shows that information and control do not go hand in hand. When the board reacts to market information promptly and effectively, it is difficult for informed traders to profit from their private information, giving them no incentive to collect information in the first place. CEO entrenchment is the underlying force that determines informativeness of the stock price and effectiveness of board monitoring in equilibrium. In the face of entrenchment, the market cannot be a disciplining force because it is not profitable to speculate.

Large shareholders are also often thought of as monitors of management because they have a greater incentive to monitor, compared to small dispersed shareholders (e.g., see Maug, 1998). Could our model of the board of directors be equally thought of disciplining by a large blockholder? A large blockholder can discipline the CEO only by influencing the board of directors, which has the sole power to fire the CEO. The entrenchment cost, $E$, subsumes the ownership structure, among other 
things. More generally, concentrated blocks of stocks are often subject to agency problems themselves because they are effectively controlled by delegated portfolio managers, who may not have incentives to monitor management. In our empirical work, we will take account of block share holdings but, as we discuss further below, the predicted sign of the effect is unclear.

\section{Empirical Hypotheses and Empirical Strategy}

In this section we set forth the empirical hypotheses following from the model and then we specify the structural empirical models; finally we explain the empirical strategy for testing.

The basic idea of the model is straightforward: conditional on control variables, a measure of informed trading should be positively related to proxies for the degree of managerial entrenchment. This is because our theoretical model shows that there is a tension between information production and monitoring by the board of directors. Since board disciplining of CEOs is costlier when the CEO is more entrenched, the CEO is less likely to be forced out. In that case, private information production is more profitable - precisely when it has no social value. Private information production is reduced, resulting in less informative stock prices, when the CEO is less entrenched. Due to this tension, we have an equilibrium model in which the informed trader's effort of information production and the board's monitoring effort are jointly determined. On the one hand, board monitoring is more effective when the market provides more accurate information, so we should observe board monitoring increases in informed trading. On the other hand, the informed trader profits are reduced by board monitoring so we should observe that informed trading decreases to the extent that board monitoring is effective. Only a simultaneous-equations model can disentangle these two effects.

\subsection{Hypotheses}

We develop our empirical analysis progressively in two steps: first, we examine reduced-form tests and second, we examine structural simultaneous-equations tests. We first put the endogeneity issue aside and estimate reduced-formed models. The hypothesis corresponding to Proposition 2 can be stated as:

Hypothesis 1: The informed trader's effort to collect information is increasing in the degree of the firm's CEO entrenchment; the board's internal monitoring effort is decreasing in the degree of CEO entrenchment. 
Reduced form estimation tests the predictions of Proposition 2 without concerns about the specification and estimation issues related to structural estimation. Although other papers in the literature (for example, Huson, Parrino, and Starks 2001) have examined the relation between CEO turnover and corporate governance, our test of the impact of CEO entrenchment on informed trading is new. The reduced-form tests enable us to check whether our theoretical comparative statics are correct before we proceed to conduct more complicated structural tests of simultaneous equations.

Because the board's monitoring effort and the informed trader's information effort are jointly determined in our theoretical model, they are both endogenous variables in empirical tests. We thus set up a structural system of simultaneous equations. Our second hypothesis corresponds to Proposition 1.

Hypothesis 2: The informed trader's effort to collect information is decreasing in the board of directors' monitoring effort; the board monitoring effort is increasing in the informed trader's information production effort.

Hypothesis 1 tests the effect of CEO entrenchment on informed trading. Hypothesis 2 takes one step further to study the interaction of informed trading and board monitoring. The study of the effect of firm performance on CEO turnover (such as Kaplan and Minton 2006 and Jenter and Kanaan 2006) is related to one of the two simultaneous equations in our model. If CEO turnover is related to firm performance, it has to be related to the force that reveals that performance in the stock market. That force is informed trading. But this is only part of the story. We show that there is another part of the story: board monitoring has a feedback effect on informed trading. We use a simultaneous-equations model to empirically characterize the whole picture.

\subsection{Empirical Specification}

For empirical tests, we use the probability of informed trading (PIN) to measure the informed trader's information production effort and the probability of forced CEO turnover (FORCETURN) to measure the board's monitoring effort. PIN is a measure developed by Easley, Kiefer, and O'Hara (1996, $1997 \mathrm{a}, \mathrm{b})$. It is based on a structural market microstructure model. ${ }^{4}$ Because forced CEO turnover is a discrete variable, that is, a CEO is either forced out of office or not, we adopt the limited-dependentvariable approach to characterize a probabilistic relation for this binary-response variable.

The structural system has two equations: the PIN equation and the FORCETURN equation.

\footnotetext{
${ }^{4}$ Easley, Hvidkjaer, and O'Hara (2002) show that stocks with a high PIN earn higher returns, to compensate investors for the higher risk of private information. PIN has become widely used in the literature.
} 
Specifically, we formulate the structural PIN equation as follows: ${ }^{5}$

$$
\text { PIN }=\alpha_{0}+\alpha_{1} * \text { FORCETURN }+\alpha_{2} * \text { Controls_PIN }+\varepsilon_{1},
$$

where FORCETURN is the dummy variable that equals one for forced CEO turnover and zero otherwise, and Controls_PIN represents a (lagged) set of control variables that have been identified as PIN determinants in the literature (see Section 4.1 below for details).

Meanwhile, we specify the structural FORCETURN equation as follows:

$$
\text { FORCETURN }=\beta_{0}+\beta_{1} * \text { PIN }+\beta_{.2} * \text { Controls_FORCETURN }+\beta_{3} * \text { Entrenchment }+\varepsilon_{2},
$$

where Controls_FORCETURN represents a (lagged) set of control variables that are known to affect the likelihood of forced CEO turnover in the literature, and Entrenchment is a set of variables that serve as proxies for CEO entrenchment, $E$, in the theoretic model. Because the dependent variable of this model, FORCETURN, is a binary variable taking on two values, zero and one, an oft-used equivalent representation of this model specification consists of the following two equations (see, e.g., Wooldridge (2002, Chapter 15)):

$$
\begin{aligned}
y^{*}= & \beta_{.0}+\beta_{1}{ }^{*} \text { PIN }+\beta_{.2}{ }^{*} \text { Controls_FORCETURN }+\beta_{.3}{ }^{*} \text { Entrenchment }+\varepsilon_{2}, \\
& \text { FORCETURN }=\mathbf{1}\left[\mathrm{y}^{*}>0\right]
\end{aligned}
$$

where the symbol 1[.] is an indicator function, and $\mathrm{y}^{*}$ is a latent variable that is linearly related to PIN, Entrenchment and the control variables affecting the board's CEO turnover decision.

\subsection{Estimation Strategy}

Given the above empirical specification, our estimation strategy consists of three parts, which are increasingly complicated and explained below.

In principle, we are only interested in the simultaneous system of equations, but as is well documented in the econometrics literature (see, e.g., Wooldridge, 2002; and Greene, 2005), there are some pitfalls to estimating the simultaneous-equation model, such as identification, endogeneity bias, model misspecification, etc. Thus, we first put aside the endogeneity issue and estimate the reduced-form of the simultaneous-equation model. The reduced-form estimation typically serves as the first step toward

\footnotetext{
${ }^{5}$ We do not include Entrenchment proxies in the structural PIN equation because our theoretical model does not yield such a direct relation between PIN and Entrenchment. Instead, our model predicts that Entrenchment is indirectly related to PIN only through the relation between Entrenchment and forced CEO turnover.
} 
estimating a system of simultaneous equations. Moreover, the reduced-form estimation tests the results of Proposition 2 without concerns about specification and estimation issues related to structural estimation of the simultaneous-equation model.

We then proceed to estimate the simultaneous-equation system. We carry out the structural estimation using two approaches. We start with a partial-information approach by estimating the system equationby-equation. That is, if we focus only on the structural PIN equation, we specify a reduced form for the FORCETURN equation; likewise, if we focus only on the structural FORCETURN equation, we specify a reduced form for the PIN equation. The essence of this partial-information approach is the two-stage-estimation method, which is known to produce consistent, but generally inefficient, estimates for parameters of a structural equation. To improve the efficiency of this partial-information approach, we use the one-step Maximum-Likelihood-Estimation (MLE) method. ${ }^{6}$ In the Appendix, we derive the likelihood functions for the MLE method. Finally, we use a full-information approach to estimate the simultaneous-equation system. Because the likelihood for the full-information approach is much more difficult to derive and the MLE is much more cumbersome to implement, we rely on the Generalized-Least-Squares (GLS) method proposed by Amemiya (1979) to conduct the fullinformation estimation. Amemiya shows that his GLS estimates are asymptotically efficient and easier to calculate than the MLE estimates.

A caveat is in order. Relative to the partial-information approach, the full-information approach takes into account the correlation between the error terms of the two structural equations and, therefore, is asymptotically more efficient (Greene, 2005). However, the full-information approach is sensitive to model specifications. If one structural equation happens to be misspecified, then the parameter estimates of both structural equations in the system would be contaminated if we use the fullinformation approach. In contrast, the partial-information approach by and large confines the misspecification problem to the particular structural equation where the problem arises. Therefore, to maintain a balance between consistency and efficiency of estimations, we estimate the simultaneousequation model with both the partial-information approach and the full-information approach. Moreover, because we conduct the partial-information estimation with MLE and the full-information estimation with GLS, respectively, such exercises provide robustness checks of our empirical analysis if the two approaches generate similar results.

\footnotetext{
${ }^{6} \mathrm{We}$ also estimate the system of simultaneous equations with the two-step partial-information estimation method. The results are qualitatively similar and are available upon request.
} 


\section{Empirical Results}

We begin this section with an introduction of the various data sources. Then we move on to the three levels of testing: reduced forms, partial-information structural estimation, and full-information structural estimation.

\subsection{Data and Summary Statistics}

\subsubsection{Data}

Data are from various sources, as well as hand collected. All stock price and stock return data come from the Center for Research in Security Prices (CRSP) Monthly Stock File and accounting information is from the Compustat Annual File. Executive information is from the Execucomp database. Institutional and blockholding data are from the Thompson Financial Institutional Holdings database. Analyst coverage information is from the Institutional Brokers Estimates System (I/B/E/S) Historical Summary file. Board composition information is obtained from the Board Analytics Database.

The two choice variables in our theoretical model are the informed trader's optimal information production effort choice and the board's disciplining effort choice. For empirical tests, we measure them by the probability of informed trading (PIN) and by the probability of forced CEO turnover (FORCETURN), respectively. The PIN measure is constructed on the basis of Easley et al.'s (1996, 1997) structural market microstructure model. We use the quarterly PIN data estimated by Stephen Brown of Emory University. ${ }^{7}$

The CEO turnover data is based on Jenter and Kanaan (2006). Their dataset covers the period from 1993 to 2001; we hand collect more data to extend the period covered through the year of 2006 . Specifically, we identify a CEO turnover (CEOTURN) for each firm and for each year in which the CEO recorded in the Standard \& Poor's Execucomp database changes. We then search the Factiva news database and the Lexus-Nexus news database for the exact turnover announcement date and classify each CEO turnover according to whether the turnover is forced or voluntary. The classification of CEO turnovers into "forced" or "voluntary" follows Parrino (1997) and Jenter and Kanaan (2006). ${ }^{8}$ The variable CEOTURN is a dummy variable that equals one if the CEO changes in

\footnotetext{
${ }^{7}$ The data is available at http://userwww.service.emory.edu/ sbrow22/index.html. We also used an annual PIN measure that we estimated; the results are similar. Because the quarterly PIN data better matches CEO turnover data in timing than the annual PIN data does, we focus on the quarterly PIN data in the paper.

${ }^{8}$ As Jenter and Kanaan (2006, p17) explain:, “....all departures for which the press reports state that the CEO is fired, forced out, or retires or resigns due to policy differences or pressure, are classified as forced. All other departures for CEOs above and including age 60 are classified as not forced. All departures for CEOs below age
} 
one specific year and zero otherwise. Similarly, FORCETURN is a dummy variable that is set to one if the CEO turnover is forced, and to zero otherwise.

To be consistent with the timing of the two choice variables in our model, we use the following rule to match PIN with FORCETURN (or, alternatively, CEOTURN). If there is no CEO turnover for a given year (i.e., CEOTURN=0), we calculate the average PIN over the four quarters prior to the calendar date corresponding to the fiscal year-end. ${ }^{9}$ On the other hand, if there is a CEO turnover in a given year (i.e., CEOTURN=1), we calculate the average PIN over the four quarters prior to the CEO turnover date. We then match the average quarterly PIN with the CEO turnover data. To match other data with the matched data of PIN and CEO turnover, we adopt the following rule. We first annualize the quarterly data by calculating the four-quarter average, then we match the annual or annualized data of year $\mathrm{t}-1$ with the CEO turnover data of year $\mathrm{t}^{10}$

For the empirical tests, we use four proxies for the degree of CEO entrenchment: the logarithm of the value of CEO tenure (LNTEN), the CEO's stock ownership as a ratio of a company's outstanding shares (CEOSH), a dummy variable indicating whether the CEO also serves as the chairman of the board of directors (DUAL), and the fraction of outside directors on the board (POD) for the firms covered in the Execucomp database. ${ }^{11}$ We extract information on CEO tenure, CEO stock ownership and CEO-Chair duality from Execucomp, if available; we supplement and/or correct these data by hand-collecting, if necessary. For DUAL, the dummy that is equal to one if a CEO is also the chair of the firm's board and to zero otherwise. We retrieve the board composition information from the Board

60 are reviewed further and classified as forced if either the article does not report the reason as death, poor health, or the acceptance of another position (including the chairmanship of the board), or the article reports that the CEO is retiring, but does not announce the retirement at least six months before the succession. Finally, the cases classified as forced can be reclassified as voluntary if the press reports convincingly explain the departure as due to previously undisclosed personal or business reasons that are unrelated to the firm's activities."

${ }^{9}$ Using annual PIN gives substantially similar results, but when a quarterly PIN series became available we switched to the quarterly data. The main reason for averaging PIN over four quarters is to try to eliminate potential estimation error. However, using just quarterly PIN again gives substantially similar results.

${ }^{10}$ As a result, the control variables are one-period lagged relative to FORCETURN (or CEOTURN); the control variables are one-period-lagged relative to PIN for the no-turnover group (CEOTURN=0) and "semi" oneperiod-lagged relative to PIN for the turnover group (CEOTUIRN=1). Following are two examples. Example 1, CEOTURN=1: say, turnover date is July 15, 2000 and the corresponding fiscal year-end is December 31, 2000. PIN is calculated as a four-quarter average over the period of July 1, 1999 to June 30, 2000. Tobin's Q is calculated at the last fiscal year-end, i.e., Dec 31, 1999. Example 2, CEOTURN=0: say, fiscal year-end is December 31, 2000. PIN is calculated as a four-quarter average over the period of Jan 1, 2000 to December 31, 2000. Tobin's Q is calculated at the last fiscal year-end, i.e., Dec 31, 1999. Aside from using the four-quarter average, we have also used in our analysis the quarterly PIN, which avoids the timing issue as shown in Example 1. The results are similar and are available upon request.

${ }^{11}$ In addition to the proxies for corporate governance and CEO entrenchment, we also looked at concentrated institutional ownership, the G-index developed by Gompers, Ishii, and Metrick (2003), and the E-index developed by Bebchuk, Cohen, and Ferrell (2004). We found the effect of these proxies to be statistically insignificant and thus did not include them in the paper. 
Analytics Database that covers the period from 1996 to 2006; we extend its coverage to the 1995-2006 period by hand collecting the board composition data for the year of $1995 .^{12}$

There are two sets of control variables, one for the structural PIN equation, Controls_PIN, and the other for the structural FORCETURN equation, Controls_FORCETURN. From the existing literature, these control variables are known to affect either PIN or forced CEO turnovers. Specifically, Controls_PIN includes the logarithm value of market capitalization (LNME), the return on assets (ROA), the one-year stock return (RET1YR), the stock beta (BETA), the one-year stock return volatility (VOL1YR), the logarithm value of share turnover (LNSHTURN), Tobin's Q (TOBIN), the logarithm value of one plus the number of analysts covering the firm (LNNUMEST), the fraction of a company's shares held by all institutional investors (INSTHOLD), the logarithm value of firm age (LNFMAGE), industry dummies (INDUSTRY), and year dummies (YEAR). We calculate ROA as the ratio of operating income after depreciation (item 178) to total assets (item 6). We calculate RET1YR as the cumulative monthly returns over the past twelve months. We estimate BETA from fitting the Capital Asset Pricing Model (CAPM) to a company's monthly stock returns over the past five years. We annualize the standard deviation in daily stock returns over the past one year to obtain VOL1YR. We divide the total number of shares traded (item 28) by the total number of shares outstanding (item 25) and take logs on the ratio to obtain LNSHTURN. We calculate TOBIN as the ratio of the market value of assets to the book value of assets, where the market value of assets equals the book value of assets (item 6) plus the market value of common equity (item 25 times item 199) minus the book value of common equity (item 60) and balance sheet deferred taxes (item 74). If the number of analyst information for a firm is missing, we set the number to zero. We compute INSTHOLD as the ratio of the total number of shares held by all institutions to the total number of shares outstanding. We calculate LNFMAGE as the logarithm value of the number of years since the CRSP begins its coverage of a firm. Finally, we use Fama and French's 49-industry definitions to classify firms into one of these industries.

Similarly, for the FORCETURN equation, Controls_FORCETURN represents a set of control variables that are documented in the literature to affect the likelihood of forced CEO turnover, including LNME, ROA, RET1YR, industry returns (INDRET), LNSHRTURN, TOBIN, LNNUMEST, logarithm value of one plus the number of blockholders (LNNUMBH), logarithm value of CEO age (LNCEOAGE), INSUTRY, and YEAR. For each of Fama and French's 49 industries, we sum over the one-year stock returns of all the firms of this industry with equal weights to calculate INDRET. We use INDRET as a benchmark that the board may use to assess CEO performance; the "relative performance" hypothesis in the literature is discussed below. A blockholder is the

\footnotetext{
${ }^{12}$ Because the quality of Execucomp data is not very high for the first few years of its coverage, we decided to focus on the period starting from 1995. We thus hand collected the board composition data for 1995 only.
} 
institutional investor that owns more than five percent of a company's shares. Besides Controls_FORCETURN, the FOCETURN equation also includes Entrenchment which is the abovementioned set of variables that serve as proxies for the CEO entrenchment, $E$, in the theoretical model.

\subsubsection{Summary Statistics}

At the intersections of the above datasets, our sample contains 16,726 firm-year observations and covers the period from 1995 to 2006 . Table 1 reports the summary statistics of these variables. Panel A summarizes the two choice variables and the four CEO entrenchment proxies. The PIN variable has a mean of 0.150 and a median of 0.140 , and its standard error is $0.072 .{ }^{13}$ The CEO turnover rate averages at 0.099 or $9.9 \%$ with a standard error of 0.299 . About one quarter of the CEO turnovers are forced: FORCETURN averages at 0.024 or $2.4 \%$ over the period with a standard error of 0.153 . For the four CEO entrenchment proxies, CEO tenure averages at about seven years (the average LNTEN equal to 1.962 years) with a minimum of one year and a maximum of 61 years (the maximum LNTEN equal to 4.111 years); the average CEO stock ownership is 0.026 or $2.6 \%$ with a median of 0.003 and a maximum of 0.642; close to two-thirds of CEOs serve as board chairs of their companies; about $80 \%$ of the directors sitting on the boards are outsiders. Note that, for each of the first three entrenchment proxies (LNTEN, CEOSH, DUAL), the higher its value, the stronger is CEO entrenchment; but for the last entrenchment proxy (POD), the higher its value, the weaker is CEO entrenchment.

Panel B of Table 1 reports the correlations for the two choice variables and the four CEO entrenchment proxies. The correlation panel provides a glimpse of several empirical relations that are supportive of our model predictions. First, the correlation coefficient between PIN and FORCETURN is small and is statistically insignificant, which is potentially in line with our model prediction that the two choice variables are endogenous and determined jointly. Second, PIN is positively and significantly correlated with CEO tenure and CEO stock ownership, and it is negatively and significantly correlated with the fraction of outside directors. This evidence is consistent with our model prediction that the optimal informed trader's effort is increasing in the degree of CEO entrenchment. Third, FORCETURN is negatively and significantly correlated with CEO tenure, CEO stock ownership, and CEO-chair duality, and it is positively and significantly correlated with the fraction of outside directors. These results echo our model prediction that the optimal board monitoring effort is decreasing in the degree of CEO entrenchment. Fourth, CEO tenure, CEO stock ownership, and CEO-chair duality are all positively and significantly correlated with each other, and both CEO tenure and CEO stock ownership are negatively and significantly correlated with the fraction of outside directors.

\footnotetext{
${ }^{13}$ For comparison, Easley, Hvidkjaer, and O'Hara (2002) report a median PIN of 0.185, mean PIN equal to 0.191 and a standard deviation of 0.057 over the 1983-1998 period.
} 
Table 1, Panel C presents the summary statistics of the control variables, which are in line with the ones reported in the empirical literatures and are not elaborated here. Notably, for an average firm in our sample, the market capitalization is 1.62 billion US dollars (average of LNME=7.390); its ROA equals 0.084 or $8.4 \%$; its beta and annualized stock return and volatility are respectively $1.061,0.201$ or $20.1 \%$, and 0.428 or $42.8 \%$; its Tobin's Q equals 2.018 ; the turnover of its shares is 1.27 (average of LNSHTURN=0.236); it has about five equity analysts (average of LNNUMEST=1.740) and two block holders (average of LNNUMBH=0.927), and $61 \%$ of its shares are held by institutional investors; the firm's age and the firm CEO's age are respectively 19 years old (average LNFMAGE=2.943) and 57 years old (average LNCEOAGE=4.037).

Table 2 shows the two choice variables PIN and FORCETURN (and CEOTURN) across fiscal years. The yearly summary statistics for the choice variables are generally similar to the pooled summary statistics. The PIN measure shows a decreasing pattern, i.e., prices are becoming less informative, across years, down from an average of 0.180 in 1995 to an average of 0.131 in 2006. The average CEO turnover rates stays around $10 \%$ per year except $2006,{ }^{14}$ and around $20 \%-25 \%$ of the CEO turnover is forced per year. Also not surprisingly, the (forced) CEO turnover rates are relatively higher for the three fiscal years, 2000, 2001, and 2002, because of the stock market crash and the ensuing economic recession during that period.

\subsection{Reduced-Form Tests}

We now proceed to formally test our key model predictions. Our model can be summarized by the two structural equations, equations (1) and (2), as seen in Proposition 1. Equation (1) characterizes the informed trader's optimal effort choice, taking as given the board's monitoring effort; and equation (2) determines the board's optimal monitoring effort, taking as given the informed trader's information production effort. Solving the two structural equations jointly, we obtain the two reduced-form equations, equations (3) and (4), as shown in Proposition 2. Accordingly, we conduct the empirical analysis in two steps: we first test Hypothesis 2 by estimating the two reduced-form equations, and afterwards, we test Hypothesis 1 by estimating the two structural equations.

From the two reduced-form equations in Proposition 2, we see that the informed trader's optimal information production effort level is increasing in the degree of CEO entrenchment (the PIN equation), and that the board's optimal replacement effort is decreasing in the degree of CEO entrenchment (the FORCETURN equation).

\subsubsection{The Reduced-Form PIN Equation}

\footnotetext{
${ }^{14}$ The average CEO turnover rate is significantly lower for fiscal year 2006 , which is $3.3 \%$. This is mainly due to the lack of CEO turnover information for this year.
} 
We first estimate the reduced-form PIN equation, which we specify as follows based on the specifications of the two structural equations:

$$
\mathrm{PIN}=\pi_{0}+\pi_{1} * \text { Entrenchment }+\pi_{2} * \text { Controls }+\eta_{1}
$$

where Entrenchment is one single proxy or, alternatively, several proxies for $\mathrm{CEO}$ entrenchment, and Controls represents the set of control variables, as explained above, which is a union of Controls_PIN and Controls_FORCETURN.

Table 3 reports the OLS estimation results of the reduced-form PIN equation using different combinations of the four CEO entrenchment proxies, with robust standard errors adjusted for clustering in firms. Consistent with earlier findings in the PIN literature (e.g., Easley et al., 2002), PIN is significantly and negatively related to firm size, share turnover, number of analysts covering the firm, aggregate institutional holding, and firm age; PIN is significantly and positively related to stock return volatility, Tobin's q, and number of blockholders. In our sample, PIN is found to be not significantly related to a firm's accounting performance or the stock's beta risk, and it is found to be negatively significantly related to CEO age only when CEO tenure is also used in the regression. Interestingly, a company's PIN is significantly negatively related to the stock performance of the industry but is significantly positively related to the stock performance of the firm. This evidence appears to suggest that the informed trader has more incentive to collect information as the stock return of a targeted firm increases relative to the stock return of the industry to which the firm belongs.

The key parameters of interest in the reduced-form PIN equation are the estimated coefficients on Entrenchment. In Models (1)-(4) we study the four Entrenchment proxies separately in the reducedform PIN equation, and in Model (5) we study the four Entrenchment proxies jointly. It is clear that the PIN variable is generally increasing in the degree of Entrenchment except when the CEO-chair duality dummy (DUAL) is used as the Entrenchment proxy. Specifically, when LNTEN (log of CEO tenure) is the only Entrenchment proxy in the regression, its estimate is 0.004 and it is significant at the $1 \%$ level; the estimates for the parameters of interest are respectively 0.047 and -0.010 when CEOSH (CEO stock ownership share) and POD (percentage of outside directors) are separately used as the Entrenchment proxy in the regression, and both estimates are statistically significant at the 5\% level. When used jointly in the regression, the three Entrenchment proxies retain parameter estimates with the same signs, similar magnitude, and significance levels as obtained when they are used separately in the regressions.

Our model predicts that because entrenched CEOs are more difficult to remove, informed traders are more likely to profit from private information and, consequently, make greater efforts to collect 
information. These results confirm that PIN increases with CEO entrenchment for three of the four entrenchment proxies.

\subsubsection{The Reduced-Form FORCETURN Equation}

We now turn to estimating the reduced-form FORCETURN equation, which is specified as follows:

$$
\text { FORCETURN }=\lambda_{\tilde{0}}+\lambda_{1} * \text { Entrenchment }+\lambda_{2} * \text { Controls }+\eta_{2}
$$

where Entrenchment and Controls are defined in the same way as in the reduced-form PIN equation. Here the dependent variable, FORCETURN, is a dummy variable that equals either zero or one. Therefore, the fitted value of this regression characterizes the probability of "success" - that is, the probability that FORCETURN=1. That said, the reduced-form FORCETURN equation specifies the probability of forced CEO turnover as a linear function of the degree of CEO entrenchment and the control variables. As discussed in Wooldridge (2002), this model of a binary-response dependent variable can be rewritten in terms of a latent variable $\mathrm{y}^{*}$ as follows:

$$
\begin{aligned}
& \mathrm{y}^{*}=\lambda_{0}+\lambda_{1} * \text { Entrenchment }+\lambda_{2} * \text { Controls }+\eta_{2}, \\
& \text { FORCETURN }=\mathbf{1}[\mathrm{y} *>0],
\end{aligned}
$$

where the symbol $\mathbf{1}[$.$] is the indicator function.$

We use the Probit model to estimate the reduced-form FORCETURN equation. ${ }^{15}$ Table 4 reports the MLE results, with robust standard errors adjusted for clustering in firms.

Looking at Table 4, we first discuss some results in relation to our control variables, which have been the focus of much previous research. Notably, consistent with earlier findings in the CEO turnover literature, the probability of forced CEO turnover is highly significantly and negatively related to firm performance, measured by either accounting performance like ROA or market performance like oneyear stock return (e.g., Weisbach, 1988; Warner, et al., 1988; Huson, et al., 2001; Jenter and Kanaan, 2006; Kaplan and Minton, 2006). The probability of forced CEO turnover is significantly and positively related to share turnover, suggesting that managers of more liquid firms are subject to more monitoring from the market and thus are more likely to be forced out of office. The relation between the likelihood of forced CEO turnover and analyst coverage is positive but quite weak and is only marginally significant at best.

Two issues deserve more attention, though they are not our central focus. Note that in line with some prior findings on the presence of weak-form relative performance evaluation (RPE) metrics in CEO

\footnotetext{
${ }^{15}$ We also used the logit model or the linear probability model to estimate the reduced-form FORCETURN equation. The results are qualitatively similar to the ones obtained from using the Probit model, though the parameter estimates have different magnitudes due to the different model choices.
} 
turnover decisions, the probability of forced CEO turnover is highly significantly and positively related to benchmark performance as measured by industry returns (INTRET). Whether or not boards of directors use the performance of other firms in the industry as a benchmark has been an empirical controversy. See Core, Guay, and Larker (2005) for a survey. Some of the authors that have addressed this issue include, among others not listed, Barro and Barro (1990), Jensen and Murphy (1990), Gibbons and Murphy (1990), and Jenter and Kanaan (2006). The weak-form RPE argument states that the board takes at least some account of the benchmark performance in evaluating managerial performance and making CEO replacement decisions. Therefore, CEO dismissals should be negatively related to firm performance, holding the benchmark performance constant, and positively related to the benchmark performance, holding firm performance constant. Our empirical evidence thus lends strong support to the weak-form RPE in CEO turnover decisions.

The second issue concerns institutional holdings and blockholders, which are not the same thing. Intriguingly, the relation between forced CEO turnover and institutional holding is found to be significantly negative in our study. ${ }^{16}$ Not surprisingly, the probability of forced CEO turnover is positively and significantly related to the number of blockholders which some researchers use as a measure of the quality of corporate governance (e.g., Bertrand and Mullainathan, 2001). Recall that the blockholder variable is the number of holders with a share greater than five percent of the total shares, so these are typically larger shareholders than the average institutional investor. The argument is that the more blockholders, the better is governance, due to stronger monitoring, so the higher is the likelihood of CEO turnover. Also, the probability of forced CEO turnover is positively and significantly related to CEO age, reaffirming the earlier finding on the influence of age on the normal retirement and CEO succession process (e.g., Huson, et al., 2001; Kaplan and Minton, 2006). In addition, we do not find significant relations between the likelihood of forced CEO turnover with the following firm characteristics: firm size, stock's beta risk, stock's total return volatility, Tobin's q and firm age.

Now, we turn to our main focus of interest, namely, the estimated coefficients on the Entrenchment proxies in the reduced-form FORCETURN equation. In Models (1)-(4) we study the four Entrenchment proxies separately in the reduced-form FORCETURN equation, and in Model (5) we jointly include the four Entrenchment proxies. All the five models clearly show that the likelihood of forced CEO turnover is decreasing in the degree of Entrenchment. Specifically, when LNTEN is the only Entrenchment proxy in the regression, its estimate is -0.596 and is significant at the $1 \%$ level; if

\footnotetext{
${ }^{16}$ The economic meaning of total institutional holding is unclear in empirical studies. Although some researchers tend to use the variable as a proxy for institutional monitoring, Chen, et al. (2007) document that it is at best a very noisy measure. Huson, et al. (2001) find no relation between the level of institutional holding and CEO turnover. Furthermore, dropping the total institutional holding variable from the regression does not qualitatively change the results for the key parameters of interest.
} 
the Entrenchment proxy is CEOSH in the regression, its estimate is -2.958 and it is significant at the $1 \%$ level; when DUAL is the only Entrenchment proxy in the regression, its estimate is -0.327 , again significant at the $1 \%$ level. The three variables, respectively standing for CEO tenure, CEO stock ownership, and CEO-chair duality, are positively correlated with each other; there is ample empirical evidence that these measures are inversely related to monitoring intensity and are positively related to weaker corporate governance/stronger CEO power (e.g., Gibbons and Murphy, 1992; Ryan and Wiggins, 2004; Hermalin, 2005). That is, the higher their values, the stronger is CEO entrenchment. Consequently, using these three variables as proxies for CEO entrenchment, we obtain the results suggesting that the likelihood of forced CEO turnover decreases with respect to the degree of entrenchment.

When we use POD, the fraction of outside directors on the board, as the proxy for CEO entrenchment in the regression, the parameter of interest is estimated to be 1.098 and is significant at the $1 \%$ level. Because POD is well known to be positively related to monitoring intensity (e.g., see Weisbach, 1988; and Yermack, 1996) and, hence, negatively related to CEO entrenchment, this result again implies that the likelihood of forced CEO turnover increases with monitoring and thus declines with entrenchment. Interestingly, when we jointly use the four proxies in the regression, only LNTEN and POD retain statistically significant coefficients, which are negative for LNTEN and positive for POD; the coefficients for the other two proxies, CEOSH and DUAL, remain negative but statistically insignificant, suggesting that CEOSH and DUAL likely capture similar information to LNTEN, thereby losing their marginal power to LNTEN in predicting the likelihood of forced CEO turnover.

To make sure that the results of Table 4 do not just reflect the effects of CEO turnover, we also estimate a bivariate Probit model (see also Huson, et al., 2001). Besides the reduced-form FORCETURN equation, the bivariate Probit model contains another equation for CEOTURN which equals one if there is a CEO turnover (of any type) and zero otherwise. The specification for the CEOTURN equation is the same as that for the reduced-form FORCETURN equation. The estimated coefficients in the reduced-form FORCETURN equation from the bivariate Probit model thus represent marginal effects on forced CEO turnover, conditional on CEO turnover taking place. ${ }^{17}$

Table 5 reports the estimation results from applying a maximum-likelihood bivariate probit model to the reduced-form FORCETURN equation; for brevity, we do not show the estimation results for the CEOTURN equation (which are available upon request). Because the results in Table 5 are very similar to the ones in Table 4, we focus on the key parameters of interest. In Models (1)-(3), when LNTEN, CEOSH, and DUAL are respectively used as the proxy for CEO entrenchment, their

\footnotetext{
${ }^{17}$ Another way to capture the marginal effects of forced CEO turnover, controlling for CEO turnover, is to estimate a multinomial Probit/Logit model. The results are qualitatively similar to the ones obtained from using the bivariate Probit model.
} 
coefficient estimates are, respectively, $-0.532,-2.719$ and -0.356 , and all are significant at the $1 \%$ level. In Model (4), when POD is used as the proxy for CEO entrenchment in the regression, the parameter of interest is estimated to be 1.016, significant at the $1 \%$ level. The results indicate that the likelihood of forced CEO turnover is significantly negatively related to CEO tenure, CEO stock ownership and CEO-chair Duality and is significantly positively related to the fraction of outside directors sitting on the board. If we include the four proxies jointly in the regression as in Model (5), both LNTEN and DUAL retain significantly negative coefficient estimates; POD has a significantly positive coefficient; CEOSH has a negative but insignificant coefficient estimate.

Overall, the results from both Table 4 and Table 5 confirm our model predictions. They clearly show that, whether or not we control for CEO turnover in the regressions, CEO entrenchment significantly affects the likelihood of forced CEO turnover. That is, the more entrenched the CEO is, the more difficult it is for the board to remove him from office.

\subsection{Structural Tests I: Equation-by-Equation Estimation}

We now proceed to test our model's two structural equations which form a simultaneous system. We first take the partial-information approach by estimating the system equation-by-equation in this subsection, and then we adopt the full-information approach by estimating the system jointly in the next subsection.

\subsubsection{The Structural PIN Equation}

For ease of reference, below we reproduce the structural PIN equation of our empirical analysis:

$$
\text { PIN }=\alpha_{0}+\alpha_{1}{ }^{*} \text { FORCETURN }+\alpha_{2} * \text { Controls_PIN }+\varepsilon_{1},
$$

where FORCETURN is the dummy variable that equals one for forced CEO turnover and zero otherwise, and Controls_PIN represents a set of control variables that are identified as PIN determinants in the literature (e.g., Easley, et al., 2002; Aslan, et al., 2006): firm size (LNME), ROA, one-year stock return (RET1YR), stock beta (BETA), stock return volatility (VOL1YR), share turnover (LNSHTURN), Tobin's q (TOBIN), number of analysts (LNNUMEST), total institutional holding (INSTHOLD), firm age (LNFMAGE), industry dummies and year dummies.

The parameter of interest in equation (6) is the coefficient associated with the other endogenous variable in the structural system, FORCETURN. Because we focus on equation-by-equation estimation, we specify FORCETURN in the format of the reduced form as in equation (12):

$$
\mathrm{y}^{*}=\lambda_{0}+\lambda_{1}{ }^{*} \text { Entrenchment }+\lambda_{2} * \text { Controls }+\eta_{2},
$$

$$
\text { FORCETURN }=1\left[y^{*}>0\right] \text {. }
$$


Note that Controls_PIN in the structural equation is a subset of Controls which we use as the control variables (other than the Entrenchment proxies) in the reduced-form equations. This exclusion restriction imposed on the structural PIN equation enables us to identify this equation in the structural system. Further, because FORCETURN is a binary variable with values equal to zero or one, we estimate the structural PIN equation based on the method of Heckman (1978) or Maddala (1983). This method considers the effect of an endogenously chosen binary treatment (FORCETURN here) on another endogenous continuous variable (PIN here), conditional on two sets of independent variables for these two endogenous variables.

Table 6 reports the maximum likelihood estimates of the structural PIN equation, with robust standard errors adjusted for clustering in firms. For brevity, we do not show the estimation results for the reduced-form FORCETURN equation. The structural PIN equation remains the same across all models; the reduced-form FORCETURN equation includes different combinations of the four Entrenchment proxies: the four proxies entering separately into the reduced-form FORCETURN equation in Models (1)-(4) and jointly into the reduced-form FORCETURN equation in Model (5). Consistent with earlier findings in the PIN literature (e.g., Easley et al., 2002), PIN is significantly and negatively related to firm size, share turnover, number of analysts, aggregate institutional holding, and firm age, and it is significantly and positively related to stock return volatility and Tobin's q. PIN is found to not be significantly related to a firm's accounting performance, stock return performance, or a stock's beta risk. Also, the reported p-values for each model, which are for the Wald test on the independence of the two equations, provide some useful statistics for model diagnostics. Because the p-values are all smaller than 0.10 in four out of the five models except for the model whereas CEOSH is the single Entrenchment proxy in the FORCETURN equation, we can reject the hypothesis that the structural PIN equation and the reduced-form FORCETURN equation are uncorrelated with each other. The mostly significant p-values illustrate the necessity of controlling for the endogeneity of FORCETURN in estimating the structural PIN equation, which Heckman's (1978) or Maddala's (1983) method does.

The parameter of interest in the structural PIN equation is the coefficient associated with the system's other endogenous variable, FORCETURN. As shown unequivocally in Table 6, no matter which combination of the four Entrenchment proxies is used in the reduced-form FORCETURN equation, the estimated coefficient of interest is always significantly negative: the parameter values stay in the range between -0.012 and -0.009 and are all significant at the 5\% level. This result indicates that PIN is negatively related to the likelihood of forced CEO turnover, thereby supporting one of the key predictions of our theoretical model -- as the likelihood of forced turnover increases, the probability of informed trading declines. According to our model, in case a CEO replacement happens, the firm's cash flow depends on the new manager's quality and the informed trader's information about the old 
CEO becomes less useful (or even useless), so the informed trader rationally spends less effort in collecting the information ex ante. In other words, the disciplining effort exercised by the board, in the form of CEO retentions/replacements, hurts the profitability of the informed trader. Thus, firms with higher likelihood of forced CEO turnovers have lower PINs.

\subsubsection{The Structural FORCETURN Equation}

Again for ease of reference, below we restate the structural FORCETURN equation:

$$
\text { FORCETURN }=\beta_{0}+\beta_{1} * \text { PIN }+\beta_{.2} * \text { Controls_FORCETURN }+\beta_{3} * \text { Entrenchment }+\varepsilon_{2} .
$$

Or equivalently,

$$
\begin{aligned}
& \mathrm{y}^{*}=\beta_{.0}+\beta_{1} * \mathrm{PIN}+\beta_{.2} * \text { Controls_FORCETURN }+\beta_{.3} * \text { Entrenchment }+\varepsilon_{2}, \\
& \text { FORCETURN }=\mathbf{1}[\mathrm{y} *>0],
\end{aligned}
$$

where the symbol 1.].] is the indicator function, and Controls_FORCETURN represents a set of control variables that are known to affect the likelihood of forced CEO turnover in the literature (e.g., Weisbach, 1988; Warner, et al., 1988; Huson, et al., 2001): ${ }^{18}$ firm size (LNME), ROA, one-year stock return (RET1YR), industry return (INDRET), share turnover (LNSHTURN), and Tobin's q (TOBIN), number of analysts (LNNUMEST), number of block holders (LNNUMBH), CEO age (LNCEOAGE), industry dummies and year dummies.

Because we estimate the simultaneous-equation model equation-by-equation and we focus on the structural FORCETURN equation, we adopt the reduced-form PIN equation:

$$
\mathrm{PIN}=\pi_{0}{ }+\pi_{1} * \text { Entrenchment }+\pi_{2} * \text { Controls }+\eta_{1},
$$

Note again that Controls_FORCETURN in the structural equation is a subset of Controls which we use as the control variables (other than the Entrenchment proxies) in the reduced-form equations. The ensuing variable exclusion restriction placed on the structural FORCETURN equation helps identify this equation. Moreover, the structural equation is essentially a binary response model (FORCETURN here) with a continuous endogenous explanatory variable (PIN here), so we follow the discussion in Wooldridge (2002, Chapter 15.7.2) to estimate this equation. Such a model can be estimated by either a two-step approach as suggested by Rivers and Vuong (1988) or a one-step MLE approach as suggested by Evans et al. (1992). But, because MLE is more efficient than the two-step approach and

\footnotetext{
${ }^{18}$ For robustness, we also use a parsimonious set of variables for Control_FORCETURN: ROA, RET1YR, LNNUMEST, LNCEOAGE, industry dummies and year dummies, which are typically chosen as explanatory variables for CEO replacements in the literature (e.g., Weisbach, 1988; Warner, et al., 1988; Huson, et al., 2001). The results, especially the estimates on the key parameters of interest, remain similar to the ones reported in the text and are available upon request.
} 
yields direct estimates of the parameters of interest, we estimate the structural FORCETURN equation with MLE.

Table 7 reports the MLE results for the structural FORCETURN equation, with robust standard errors adjusted for clustering in firms. Reaffirming earlier findings, in all models, the likelihood of forced CEO turnover is significantly negatively related to ROA or Tobin's q (TOBIN); the likelihood is significantly negatively related to the one-year stock return (RET1YR) but significantly positively related to the industry return (INDRET), consistent with the weak-form RPE argument that the board uses the benchmark measure to make CEO retention/replacement decisions. The likelihood of forced CEO turnover is significantly positively related to share turnover (LNSHRTURN), number of analysts (LNNUMEST) and CEO age (LNCEOAGE), and it is unrelated to firm size (LNME). Different from the reduced-form estimation results, the number of block holders (LNNUMBH) appears to have no role in affecting the likelihood of forced CEO turnover in the structural estimation. With regard to the coefficient on Entrenchment, the likelihood of forced turnover is strongly related to the degree of CEO entrenchment: negatively to CEO tenure (LNTEN), CEO stock ownership (CEOSH) and CEO-chair duality (DUAL), and positively to the fraction of outside directors (POD). These parameter estimates once more confirm the prediction of our theoretical model: a CEO is less likely to be removed when he is more entrenched and the board has to bear a higher cost of removing him.

The main parameter of interest in this structural equation is the coefficient associated with the system's other endogenous variable, PIN. In four out of the five specifications, this coefficient is estimated to be positive and significant at the 5\% level, suggesting that the likelihood of forced CEO turnover increases as the probability of informed trading increases. The only exception is when the CEO-chair duality (DUAL) is used as the single CEO entrenchment proxy in the structural FORCETURN equation, and the structural coefficient on PIN remains positive but statistically insignificant. The results suggest that the boards of firms do make use of the market information to monitor CEOs, confirming the prediction of our theoretical model. According to our model, when the market is more efficient (in the sense of incorporating private information into stock prices), an unqualified CEO is more likely to be identified, and the board is more willing to make efforts to fire him.

Table 7 also reports the p-values of the estimations for model diagnostics. The p-values are the statistics of the Wald test of exogeneity, that is, under the null hypothesis that the structural FORCETURN equation is exogenous to the reduced-form PIN equation, i.e., the error term in the structural FORCETURN equation and the error term in the reduced-form PIN equation are uncorrelated. It is clear that the p-values of the five model are all lower than 0.07 except for the model whereas DUAL is the single CEO entrenchment proxy in the structural FORCETURN equation. The 
low p-values indicate rejection of the null hypothesis and are in favor of the endogeneity of PIN in the empirical analysis, justifying our use of the estimation method of Wooldridge (2002, Chapter 15.7.2) to identify the impact of informed trading on board decisions regarding CEO replacements.

Overall, the results from estimating the structural FORCETURN equation support the prediction of our theoretical model. That is, the board's optimal internal monitoring effort, in the form of CEO replacements, is increasing in the intensity of external information effort measured by the probability of informed trading; also, the board's optimal internal monitoring effort is decreasing in the degree of CEO entrenchment.

\subsection{Structural Tests II: Joint Estimation}

The equation-by-equation estimation of a simultaneous-equation model is well-known to be consistent but not efficient because such estimation fails to accommodate the correlation between the error terms of the two equations (e.g., Green, 2005). To gain efficiency (to the extent that the two equations in the system are correctly specified), we also carry out a joint estimation of the system. Because one of the endogenous variables in our system, FORCETURN, is a dummy variable that takes on only two values, zero and one, the 3-Stage-Least-Square (3SLS) method typically used for the joint estimation of a simultaneous-equation model is not appropriate for our model. ${ }^{19}$ Instead, we use the Generalized Least Square (GLS) method proposed by Amemiya (1979).

The simultaneous-equation model consists of the structural PIN equation, as in equation (6), and the structural FORCETURN equation, as in equation (7) (or the equivalent representation shown by equations (8) and (9)). The two different sets of control variables used in the two structural equations implicitly impose an exclusion restriction on each of the two equations, thereby helping identify the system of equations. ${ }^{20}$ Given the identification, the GLS method takes care of the endogeneity bias and the correlation between the error terms of the two equations, both associated with the estimation of a simultaneous-equation model. Compared to the equation-by-equation estimation which is a limitedinformation test, the GLS approach is a full-information estimation method.

Table 8 reports the GLS results from the joint estimation of the structural system, which are qualitatively similar to the ones obtained from the equation-by-equation estimation of the system. Note that, because we use five different combinations of Entrenchment proxies in the structural FORCETURN equation, the estimates for the structural PIN equation vary accordingly.

\footnotetext{
${ }^{19}$ To start we actually fit a 3SLS model to our structural system, treating the structural FORCETURN equation as a linear probability model. The results are qualitatively similar to the ones reported in the text and are available upon request.

${ }^{20}$ The FORCETURN equation belongs to the set of limited-dependent-variable models, which is essentially a nonlinear model. The nonlinearity of this equation also helps the identification.
} 
Let us first examine the structural PIN equation. Across the five sets of estimates, we note the following. First, the coefficient on the other endogenous variable FORCETURN is negative and significant at the $1 \%$ level in four of the five cases; the only exception is when CEO-chair duality is used as the single proxy for CEO entrenchment; in that case, the coefficient on FORCETURN is negative but insignificantly different from zero. This result lends support to our model prediction that the informed trader's optimal effort to collect information is decreasing in the likelihood of the board's removing the CEO. Second, consistent with the PIN literature, PIN is negatively related to firm size, share turnover, analyst coverage, aggregate institutional holding and firm age and is positively related to stock return volatility and Tobin's q.

Looking at the estimates of the structural FORCETURN equation, several patterns emerge. First, the coefficient on the other endogenous variable, PIN, is positive and significant at the $10 \%$ level in four out of the five cases; the only exception is again when CEO-chair duality is used as the single proxy for CEO entrenchment, and the coefficient on PIN remains positive but becomes statistically insignificant. This result confirms our model prediction that the board's optimal disciplining effort in the form of CEO replacement is increasing in the informed trader's effort to collect information. Second, the likelihood of forced CEO turnover relates significantly and negatively to CEO tenure, CEO stock ownership and CEO-chair duality, and the likelihood relates significantly and positively to the fraction of outside directors. The results support another prediction of our theoretic model that the board's optimal internal monitoring effort is decreasing in the degree of CEO entrenchment. Third, for all five model specifications, the likelihood of forced CEO turnover is significantly negatively related to the firm-level stock return but significantly positively to the industry-level return, supporting the weak-form RPE argument that the board uses the benchmark performance to make CEO retention/replacement decisions. Finally, across all the five model specifications, the estimated coefficients on ROA and Tobin's q are significantly negative; the estimated coefficients on share turnover, analyst coverage, and CEO age are significantly positive; and the estimated coefficients on firm size and block holding are statistically insignificant. These results are consistent with most of the above findings based on the reduced-form estimation and the partial-information structural estimation, and they also echo the earlier findings by the CEO turnover literature.

In summary, the results from the full-information approach estimation show that, in four out of five cases, the PIN equation has a significantly negative loading on FORCETURN, and the FORCETURN equation has a significantly positive coefficient on PIN. Also for the structural FORCETURN equation, the signs of the estimated coefficients on different CEO entrenchment proxies are consistent with the notion that the likelihood of forced CEO turnover declines with respect to the degree of CEO entrenchment. These results lend strong support to our model predictions. That is, if we use the probability of informed trading as the proxy for external information effort and the likelihood of 
forced CEO turnover as the proxy for internal monitoring of the board, then the external information effort is decreasing in the board's internal monitoring effort; in contrast, the board's optimal internal monitoring effort is increasing in the intensity of external information effort. Moreover, the likelihood of forced CEO turnover is decreasing in the degree of CEO entrenchment.

\section{Extension: Impact of Regulatory Oversight (on Informed Trading)}

Our theoretical model predicts a positive relation between the degree of entrenchment and market efficiency, i.e., the extent of private information production in the market. In this section, we use our model to examine a particular example of an exogenous shift in regulatory oversight that possibly brought about a change in CEO entrenchment. If the change in regulations reduces CEO entrenchment and lowers the cost of the board's monitoring effort, then, according to our model prediction, it will also reduce the intensity of informed trading in the market. We examine this prediction with regard to one episode of the regulatory oversight change: the enactment of the Sarbanes-Oxley Act of 2002 (SOX), which aims to strengthen governance in corporate America in response to a series of corporate scandals and collapses in the first few year of the $21^{\text {st }}$ century. The SOX Act is the most important legislation affecting corporate reporting and governance in the U.S. since the 1930s, yet it has been very controversial and there is a large, but inconclusive literature on the subject; see, e.g., Romano (2005), Coates (2007), Li, Pincus, and Rego (2008), and the references therein. If SOX has been effective, then we expect that the activeness of informed trading in the market decreases after it was enacted, that is, PIN goes down in the post-SOX period relative to the pre-SOX period.

We define a dummy variable, DSOX, which is equal to one for the post-SOX period (i.e., fiscal years 2003 through 2005), and zero otherwise. ${ }^{21}$ Table 9, Panel A shows the summary statistics of the four CEO entrenchment proxies for the pre-SOX period (DSOX=0) and the post-SOX period (DSOX=1) respectively. It is clear that SOX appears to have reduced CEO entrenchment and strengthened the board's monitoring of CEOs: after SOX, CEO tenure, CEO stock ownership, and percentage of CEOChair duality all decrease and the fraction of outsiders sitting on the board increases. Specifically, the average value of CEO tenure reduces from 7.4 years $(\mathrm{LNTEN}=2.004)$ in the pre-SOX period to 6.5 years $(\mathrm{LNTEN}=1.873)$ in the post-SOX period; CEO stock ownership declines from $2.92 \%$ in the preSOX period to $2.00 \%$ in the post-SOX period; the percentage of CEO also serving as the board's chair shrinks from $67.92 \%$ in the pre-SOX period to $60.11 \%$ in the post-SOX period; and the fraction of outsider board members rises from $77.28 \%$ in the pre-SOX period to $81.90 \%$ in the post-SOX period. Table 9, Panel B reports the pairwise correlations between the SOX dummy variable and the four CEO

\footnotetext{
${ }^{21}$ Including fiscal year 2002 in the post-SOX period yields similar result. Note that, here, we drop from our sample the observations for fiscal year 2006. Due to the data availability when we started this project, we have significantly fewer cases of (forced) CEO turnover for 2006 (see Table 2 and Footnote 14), which causes the lack of power in testing for the impact of SOX on forced CEO turnover and, in turn, on PIN.
} 
entrenchment proxies. Consistent with the summary statistics, the dummy variable is negatively correlated with CEO tenure, CEO stock ownership, and CEO-Chair duality, and it is positively correlated with fraction of outsider board members; all these correlation coefficients are significant with p-value equal to zero.

Given the evidence that SOX has exerted an impact on CEO entrenchment, we include the SOX dummy, DSOX, but not the four proxies for CEO entrenchment when specifying empirical models for the PIN equation and the FORCETURN equation. ${ }^{22}$ Table 10 reports the estimation results for the reduced-form FORCETURN equation (in the left half) and the reduced-form PIN equation (in the right half). Let us first look at the FORCETURN equation. As expected, the likelihood of forced CEO turnover increases in the post-SOX period after controlling for other factors that may also affect the board's decision on CEO turnover. Specifically, if we include the year dummies for 1996-2002 in the reduced-form FORCETURN equation, the estimated coefficient on DSOX equals 0.216 with a robust standard error of 0.110; if we exclude the year dummies in the FORCETURN equation, the estimated coefficient on DSOX equals 0.129 with a robust standard error of 0.058 ; both estimates are significant at the 5\% level. Against the backdrop of the tension between the board's monitoring effort and the informed traders' information production, an increase in the likelihood of forced CEO turnover after SOX implies a decrease in the intensity of informed trading in the market. This is exactly the case when we examine the results for the reduced-form PIN equation. As shown in the right half of Table 10, if we include the year dummies for 1996-2002 into the reduced-form PIN equation, the estimated coefficient on DSOX equals -0.029 with a robust standard error of 0.002 ; if we exclude the year dummies in the PIN equation, the estimated coefficient on DSOX equals -0.006 with a robust standard error of 0.002 ; both estimates are significant at the $1 \%$ level.

We also estimate the structural PIN equation by including DSOX in the model. Table 11 presents the estimation results. Consistent with our prior results, PIN is negatively related to FORCETURN, suggesting that the increased likelihood of forced CEO turnover reduces the informed trader's incentive to engage in informed trading. Moreover, PIN is again negatively correlated with the SOX dummy, DSOX. With the year dummies for 1996-2002 included in the structural specification of the PIN equation, the estimated coefficient on DSOX is -0.028 with a robust standard error of 0.002 and is significant the $1 \%$ level; if we do not include the year dummies in the PIN equation, the estimated

\footnotetext{
${ }^{22}$ If we include the four CEO entrenchment proxies along with the SOX dummy in empirical models, the coefficient estimate on DSOX becomes insignificant and the coefficient estimates on the entrenchment proxies remain significant with the same signs as in the above-reported results. The loss of statistical significance on DSOX can be attributable to the fact that SOX has affected the entrenchment proxies and that DSOX, as a dummy variable, is less informative or powerful than the entrenchment proxies in characterizing the relations of interest.
} 
coefficient on DSOX is -0.007 with a robust standard error of 0.002 and is also significant at the $1 \%$ level.

In summary, using both reduced-form specifications and structural specifications, we find that the likelihood of forced CEO turnover increases significantly after SOX; we also find that PIN decreases significantly in the post-SOX period relative to the pre-SOX period. This evidence is consistent with our model prediction: PIN goes down if there is an exogenous shift in regulatory oversight that reduces managerial entrenchment and strengthens the board's monitoring of firm managers. The channel through which the regulatory change affects informed trading is illustrated in our model, that is, the tension between the board's monitoring effort and the informed trader's information production effort.

\section{Conclusion}

The efficiency of stock prices can be used to improve social efficiency if the information in stock prices is used to make allocative decisions by firms (see Dow and Gorton 1997). We examine the interaction between the production of information by participants in the stock market and the decisions of firms. What is the link between stock market efficiency and economic efficiency? We present a theoretical model to investigate how the board of directors' monitoring of the CEO is related to the extent of private information production about that firm in the stock market. Although the board can use the private information reflected in the stock market to guide the managerial turnover decisions, the board's reaction to the market information feeds back to create a disincentive for the informed trader to collect information in the first place. The interaction between the board's decision and the informed trader's decision determines the equilibrium informativeness of stock prices and the intensity of board monitoring. The market price incorporates the informed trader's information, which is retrospective, and the board's turnover decision, which is prospective. Information produced in the stock market is highest with regard to firms that are the least likely to use that information for allocative decisions. Stock prices are more informative when the information has less social value.

We then empirically test the models' predictions. We analyze both the reduced form and the structural form of the equations that characterize the equilibrium of our model. In particular, we estimate a simultaneous-equation system that incorporates the interaction between the decisions of the informed traders and the decisions of the board of directors. Our empirical analysis proceeds in three steps, gradually adding more structure to the equations to be estimated. We start with reduced forms, which impose the least structure, and end by imposing the most structure in the full simultaneous system. Our empirical analysis confirms our model predictions. That is, if we use the probability of informed trading (PIN) as the proxy for the decisions of the informed traders and the likelihood of forced CEO turnover as the proxy for board monitoring, then informed trading is decreasing in the board's 
monitoring effort; in contrast, the board's optimal monitoring effort is increasing in the informativeness of price. Moreover, the degree of CEO entrenchment has an impact on the interaction between informed trading and CEO turnover.

Finally, we evaluate the Sarbanes-Oxley Act of 2002, finding that with respect to corporate governance, the Act reduced managerial entrenchment. Accordingly it has created a disincentive for informed trading. In some sense, the feedback effect moderates the effectiveness of changes in regulations. 


\section{References}

Adams, R. and D. Ferreira, 2007, “A Theory of Friendly Boards," Journal of Finance, 62, 217-250.

Amemiya, T., 1979, "The Estimation of a Simultaneous-Equation Tobit Model," International Economic Review, 20, 169-181.

Aslan, H., D. Easley, S. Hvidkjaer, and M. O'Hara, 2006, "The Determinants of Informed Trading: Implications for Asset Pricing," Working paper, Cornell University.

Baker, M., J. Stein, and J. Wurgler, 2003, "When Does the Market Matter? Stock Prices and the Investment of Equity-Dependent Firms," Quarterly Journal of Economics, 118, 969-1006.

Bakke, T. E. and T. M. Whited, 2008, "Which Firms Follow the Market? An Analysis of Corporate Investment Decisions," Review of Financial Studies, Forthcoming.

Barro, J.R., and R.J. Barro, 1990, "Pay, Performance, and Turnover of Bank CEOs," Journal of Labor Economics, 8, 448-481.

Bebchuk, L., A. Cohen, and A. Ferrell, 2004, "What Matters in Corporate Governance," Harvard Law School John M. Olin Center Discussion Paper No. 491, Review of Financial Studies, forthcoming.

Bernanke, B. and M. Gertler, 1989, “Agency Costs, Net Worth, and Business Fluctuations," American Economic Review, 79, 14-31.

Bertrand, M., and S. Mullainathan, 2001. "Are CEOs Rewarded for Luck? The Ones without Principals Do," Quarterly Journal of Economics, 116, 901-932.

Brown, S., S.A. Hillegeist, and K. Lo, 2004, "Conference Calls and Information Asymmetry," Journal of Accounting \& Economics, 37, 343-366.

Chen, Q., I. Goldstein, and W. Jiang, 2007, "Price Informativeness and Investment Sensitivity to Stock Price," Review of Financial Studies, 20, 619-650.

Chen, X., J. Harford, and K. Li, 2007, "Monitoring: Which Institutions Matter?" Journal of Financial Economics, 86, 279-305.

Coates, John (2007), "The Goals and Promise of the Sarbanes-Oxley Act," Journal of Economic Perspectives, Vol. 21, No. 1, 91-116.

Core, John, Wayne Guay, and David Larker, 2003, "Executive Equity Compensation: A Survey," Economic Policy Review, Federal Reserve Bank of New York, 9, 27-50.

Dow, J., I. Goldstein, and A. Guembel, 2007, "Incentives for Information Production in Markets Where Prices Affect Real Investment," Working Paper, University of Pennsylvania.

Dow, J. and G. Gorton, 1997, "Stock Market Efficiency and Economic Efficiency: Is There a Connection?" Journal of Finance, 52, 1087-1129.

Dow, J., G. Gorton and A. Krishnamurthy, 2005, "Equilibrium Asset Prices and Investment under Imperfect Corporate Control," American Economic Review, 95, 659 - 681. 
Dow, J. and R. Rahi, 2003, "Informed Trading, Investment, and Economic Welfare," Journal of Business, 76, 430-454.

Dye, R. and S. Sridhar, 2002, "Resource Allocation Effects of Price Reactions to Disclosures," Contemporary Accounting Research, 19, 385-410.

Easley, D., S. Hvidkjaer, and M. O'Hara, 2002, "Is Information Risk a Determinant of Asset Returns?" Journal of Finance, 57, 2185-2221.

Easley, D., N.M. Kiefer, and M. O'Hara, 1996, "Cream-Skimming or Profit-Sharing? The Curious Role of Purchased Order Flow," Journal of Finance, 51, 811-833.

Easley, D., N.M. Kiefer, and M. O'Hara, 1997a, "The Information Content of the Trading Process," Journal of Empirical Finance, 4, 159-186.

Easley, D., N.M. Kiefer, and M. O'Hara, 1997b, "One Day in the Life of a Very Common Stock," Review of Financial Studies, 10, 805-835.

Evans, W.N., W.E. Oates, and R.M. Schwab, 1992, "Measuring Peer Group Effects: A Study of Teenage Behavior," Journal of Political Economy, 100, 966-991.

Fich, Eliezer, 2005, "Are Some Outside Directors Better than Others? Evidence from Director Appointments by Fortune 1000 Firms," Journal of Business, 78, 1943-1971.

Fich, Eliezer and Anil Shivdasani, 2007, "Financial Fraud, Director Reputation, and Shareholder Wealth," Journal of Financial Economics, 86, 306-336.

Fishman, Michael J. and Kathleen Hagerty. 1992, "Insider Trading and the Efficiency of Stock Prices," RAND Journal of Economics, 23, 106-122.

Gibbons, R. and K.J. Murphy, 1990, "Relative Performance Evaluation for Chief Executive Officers," Industrial and Labor Relations Review, 43, 30-51.

Gibbons, R. and K.J. Murphy, 1992, "Optimal Incentive Contracts in the Presence of Career Concerns: Theory and Evidence," Journal of Political Economy, 100, 468-505.

Gilson, Stuart, 1990, "Bankruptcy, Boards, Bank and Blockholders: Evidence on Changes in Corporate Ownership and Control when Firms Default," Journal of Financial Economics, 27, 355-387.

Gompers, Paul A., Ishii, Joy L., and Metrick, Andrew, "Corporate Governance and Equity Prices", Quarterly Journal of Economics, 118, 107-155.

Green, W.H., 2005, Econometric Analysis, $7^{\text {th }}$ edition, Prentice Hall, Upper Saddle River, NJ.

Heckman, J. J., 1978, "Dummy Endogenous Variables in a Simultaneous Equation System," Econometrica, 46, 931-959.

Hermalin, B., 2005, "Trends in Corporate Governance," Journal of Finance, 50, 2351-2384.

Hermalin, B. and M. Weisbach, 1998, "Endogenously Chosen Boards of Directors and Their Monitoring of the CEO," American Economic Review, 88, 96-118. 
Hermalin, B. and M. Weisbach, 2003, "Boards of Directors as an Endogenously Determined Institution: A Survey of the Economic Literature," Economic Policy Review, Vol. 9, 7-26.

Holmstrom, Bengt and Tirole, Jean, 1993, "Market Liquidity and Performance Monitoring," Journal of Political Economy, 101, 678-709.

Huson, M. R., R. Parrino, and L.T. Starks, 2001, "Internal Monitoring Mechanisms and CEO Turnover: A Long Term Perspective," Journal of Finance, 56, 2265-2297.

Jensen, M., 1986, "The Agency Costs of Free Cash Flow: Corporate Finance and Takeovers," American Economic Review, 76, 323-330.

Jensen M. and K. Murphy, 1990, "Performance Pay and Top-Management Incentives," Journal of Political Economy, 98, 225-262.

Jenter, D. and F. Kanaan, 2006, "CEO Turnover and Relative Performance Evaluation," Working Paper, Stanford University.

Kaplan, Steven and David Reishus, 1990, "Outside Directorships and Corporate Performance," Journal of Financial Economics, 27, 389-410.

Kaplan, Steven and Bernadette Minton, 2006, "How Has CEO Turnover Changed? Increasingly Performance Sensitive Boards and Increasingly Uneasy CEOs," Working Paper, University of Chicago.

Khanna, N., S. Slezak, and M. Bradley, 1994, "Insider Trading, Outside Search, and Resource Allocation: Why Firms and Society May Disagree on Insider Trading Restrictions," Review of Financial Studies, 7, 575-608.

Kyle, A., 1985, “Continuous Auctions and Insider Trading,” Econometrica, 53, 1315-1336.

Leland H, 1992, “Insider Trading: Should it be Prohibited?" Journal of Political Economy, 100, 859887

Li, Haidan, Morton Pincus, and Sonja Olhoft Rego (2008), "Market Reaction to Events Surrounding the Sarbanes-Oxley Act of 2002 and earnings Management," Journal of Law and Economics, Vol. 51, 111-134.

Luo, Y., 2005, "Do Insiders Learn from Outsiders? Evidence from Mergers and Acquisitions," Journal of Finance, 60, 1951-1982.

Maddala, G.S., 1983, Limited-dependent and Qualitative Variables in Econometrics (Cambridge: Cambridge University Press).

Maug, E., 1998, "Large Shareholders as Monitors: Is There a Trade-Off between Liquidity and Control?" Journal of Finance, 53, 65- 98.

Parrino, R., 1997, "CEO Turnover and Outside Succession: A Cross-Sectional Analysis," Journal of Financial Economics, 46, 165-197.

Rivers, D., and Q.H, Vuong, 1988, "Limited Information Estimators and Exogeneity Tests for Simultaneous Probit Models," Journal of Econometrics, 39, 347-366. 
Romano, Roberta (2005), "The Sarbanes-Oxley Act and the Making of Quack Corporate Governance," 114 Yale Law Journal 1521.

Ryan, H. and R. Wiggins, 2004, "Whose is in Whose Pocket? Director Compensation, Board Independence, and Barriers to Effective Monitoring," Journal of Financial Economics, 73, 497-524.

Subrahmanyam, A. and S. Titman, 1999, "The Going-Public Decision and the Development of Financial Markets," Journal of Finance, 54, 1045-1082.

Warner, J.B., R.L. Watts, and K. Wruck, 1988, “Stock Prices and Top Management Changes,” Journal of Financial Economics, 20, 461-492.

Weisbach, M., 1988, "Outside Directors and CEO Turnover," Journal of Financial Economics, 20, 431-460.

Wooldridge, J.M., 2002, Econometric Analysis of Cross Section and Panel Data (MIT Press, Cambridge, MA).

Yermack, David, 1996, "Higher Valuation of Companies with a Small Board of Directors," Journal of Financial Economics, 40, 185-212. 


\section{Appendix: Derivation of Log-likelihoods for MLE}

For notational convenience, define

$\mathrm{X}_{1}=\{1$, Controls_PIN $\}$, the set of exogenous variables in the structural equation of PIN;

$\mathrm{X}_{2}=\{1$, Controls_FORCETURN, Entrenchment Proxies $\}$, the set of exogenous variables in the structural equation of FORCETURN;

Controls $=\{1$, Controls_PIN, Controls_FORCETURN $\}$, the set of all exogenous variables except for CEO entrenchment proxies; and

$\mathrm{X}=\left\{\mathrm{X}_{1}, \mathrm{X}_{2}\right\} \equiv\{$ Controls, Entrenchment Proxies $\}$, the set of all exogenous variables in the system.

\section{Part 1: The structural PIN equation}

The derivation of the likelihood follows Heckman (1978) and Maddala (1983).

The system used to estimate the structural PIN equation is:

PIN $=\alpha_{0}+\alpha_{1}{ }^{*}$ FORCETURN $+\alpha_{2} *$ Controls_PIN $+\varepsilon_{1} \equiv \alpha_{1}{ }^{*}$ FORCETURN $+\alpha^{*} \mathrm{X}_{1}+\varepsilon_{1}$,

and

FORCETURN $=\lambda_{0}+\lambda_{1}{ }^{*}$ Entrenchment $+\lambda_{2}{ }^{*}$ Controls $+\eta_{2} \equiv \lambda * X+\eta_{2}$

where $\varepsilon_{1}$ and $\eta_{2}$ are bivariate normal with mean zero, $\operatorname{Var}\left(\varepsilon_{1}\right)=\sigma_{\varepsilon}^{2}, \operatorname{Var}\left(\eta_{2}\right)=1$ and $\operatorname{Corr}\left(\varepsilon_{1}, \eta_{2}\right)=\rho_{1}$.

Rewrite equation (A.2) as follows:

$\mathrm{y}^{*}=\lambda * \mathrm{X}+\eta_{2}$

$\mathrm{D} \equiv \mathrm{FORCETURN}=1[\mathrm{y} *>0]$.

Step 1. Rewrite the above equations into the reduced-form system as

$\mathrm{PIN}=\pi_{1} * \mathrm{X}_{1}+\pi_{2} * \mathrm{X}_{2}+\mathrm{v}_{1}$

$y^{*}=\lambda * X+\eta_{2}$

$\mathrm{D}=1\left[\mathrm{y}^{*}>0\right]$,

Given the identification of the system, we can solve the structural parameter estimates $\alpha$ from the reduced-form parameter estimates $\pi$ as (see Heckman (1978) for the functional form):

$\alpha=\mathrm{g}(\pi)$, or $\pi=\mathrm{g}^{-1}(\alpha)$. 
Step 2. Based on the reduced-form, we can write down the joint density of (PIN, D) as follows:

$$
f(P I N, \mathrm{D})=\left(\int_{-\lambda * \mathrm{X}}^{\infty} h\left(v_{1}, \eta_{2}\right) d \eta_{2}\right)^{D}\left(\int_{-\infty}^{\lambda * \mathrm{X}} h\left(v_{1}, \eta_{2}\right) d \eta_{2}\right)^{1-D}
$$

where $\mathrm{v}_{1}=\mathrm{PIN}-\pi_{1} * \mathrm{X}_{1}-\pi_{2} * \mathrm{X}_{2}$, and $\mathrm{h}(. .$.$) is the pdf of a bivariate normal distribution.$

Substituting equation (A.3b) into equation (A.3c), we can rewrite the joint density in terms of the identified structural parameters $\alpha$.

Specifically, the log likelihood for an observation is as follows:

$$
\begin{aligned}
\text { Loglike }= & \mathrm{D}^{*}\left\{\ln \left[\Phi\left(\mathrm{V}_{1}\right)\right]-0.5^{*}\left[\left(\mathrm{PIN}-\alpha^{*} \mathrm{X}_{1}-\alpha_{1}\right) / \sigma_{\varepsilon}\right]^{2}-0.5^{*} \ln \left[2 \pi \sigma_{\varepsilon}^{2}\right]\right\}+ \\
& (1-\mathrm{D}) *\left\{\ln \left[\Phi\left(\mathrm{V}_{2}\right)\right]-0.5^{*}\left[\left(\mathrm{PIN}-\alpha^{*} \mathrm{X}_{1}\right) / \sigma_{\varepsilon}\right]^{2}-0.5^{*} \ln \left[2 \pi \sigma_{\varepsilon}^{2}\right]\right\},
\end{aligned}
$$

where $\Phi$ is the $c d f$ of a standard normal distribution,

$$
\begin{aligned}
& \mathrm{V}_{1}=\left[\lambda * \mathrm{X}+\left(\mathrm{PIN}-\alpha^{*} \mathrm{X}_{1}-\alpha_{1}\right) * \rho_{1} / \sigma_{\varepsilon}\right] /\left[1-\rho_{1}^{2}\right]^{0.5}, \text { and } \\
& \mathrm{V}_{2}=\left[-\lambda * \mathrm{X}-\left(\mathrm{PIN}-\alpha^{*} \mathrm{X}_{1}\right) * \rho_{1} / \sigma_{\varepsilon}\right] /\left[1-\rho_{1}\right]^{0.5}
\end{aligned}
$$

Sum over all the observations and we obtain the likelihood function for MLE.

\section{Part 2: The structural FORCETURN equation}

The derivation of the likelihood follows Wooldrige (2002, Chapter 15.7.2).

The system used to estimate the structural FORCETURN equation is:

$\mathrm{y}^{*}=\beta_{\tilde{.}}+\beta_{1} * \mathrm{PIN}+\beta_{2} *$ Controls_FORCETURN $+\beta_{.3} *$ Entrenchment $+\varepsilon_{2} \equiv \beta_{1} * \mathrm{PIN}+\beta^{*} \mathrm{X}_{2}+\varepsilon_{2}$

$\mathrm{D} \equiv \mathrm{FORCETURN}=1\left[\mathrm{y}^{*}>0\right]$,

and

PIN $=\pi_{0}+\pi_{1}^{*}$ Entrenchment $+\pi_{2} *$ Controls $+\eta_{1} \equiv \pi_{*} X+\eta_{1}$

Note that, under the joint normality of $\left(\varepsilon_{2}, \eta_{1}\right)$, with $\operatorname{Var}\left(\varepsilon_{2}\right)=1$ which is normalized so as to identify the parameters of an ordinary Probit model, we decompose $\varepsilon_{2}$ as

$$
\varepsilon_{2}=\rho_{2} / \sigma_{\eta} * \eta_{1}+\mathrm{e}_{1}
$$

where $\rho_{2}$ is the correlation between $\varepsilon_{2}$ and $\eta_{1}, \sigma_{\eta}$ is the standard error of $\eta_{1}$, and $e_{1}$ is independent of $X$ and $\eta_{1}$. Note that $e_{1}$ is normally distributed with mean 0 and variance $1-\rho_{2}^{2}$.

Thus, the joint density of (D, PIN) is

$$
f(D, P I N \mid X)=f(D \mid P I N, X) * f(P I N \mid X)
$$




$$
=\{\Phi(\mathrm{W})\}^{\mathrm{D}} *\{1-\Phi(\mathrm{W})\}^{(1-\mathrm{D})} *\left(1 / \sigma_{\eta}\right) * \varphi\left[\left(\mathrm{PIN}-\gamma^{*} \cdot \mathrm{X}\right) / \sigma_{\eta}\right],
$$

where $\Phi$ and $\varphi$ are the cdf and pdf of a normal distribution, and

$$
\mathrm{W} \equiv \beta_{1}{ }^{*} \mathrm{PIN}+\beta^{*} \mathrm{X}_{2}+\rho_{2} / \sigma_{\eta} *\left(\mathrm{PIN}-\pi^{*} \mathrm{X}\right) /\left(1-\rho_{2}^{2}\right)^{0.5} .
$$

Take logs and sum over all the observations, and we derive the likelihood function for MLE. 


\section{Table 1. Summary Statistics}

Panel A presents summary statistics of the probability of informed trading (PIN), CEO turnover (CEOTURN), Forced CEO turnover (FORCETURN), and proxies for the cost of firing CEOs such as logarithm value of CEO tenure (LNTEN), CEO serving as a board chair (DUAL), CEO's stock ownership as a ratio of a company's total shares outstanding (CEOSH), and fraction of outside directors on the board (POD), for a sample of firms covered in Execucomp database over the period from 1995 to 2006. All the three variables, CEOTURN, FORCETURN and DUAL, are dummy variables, whereas CEOTURN equals one if the CEO changes in one specific year and zero otherwise, FORCETURN is set to one if the CEO turnover is forced and to zero otherwise, and DUAL equals one if a CEO is also the chair of the firm's board and zero otherwise. Panel B shows the correlations among the variables, with $p$-values in parentheses. Panel $\mathrm{C}$ lists summary statistics of control variables such as logged value of market capitalization (LNME), ROA, one-year firm-level stock return (RET1YR), one-year industry return (INDRET), stock beta (BETA), one-year stock return volatility (VOL1YR), logged share turnover (LNSHTURN), Tobin's Q (TOBIN), logged value of one plus number of analysts (LNNUMEST), proportion of a company's shares held by all institutional investors (INSTHOLD), logged value of one plus the number of block holders (LNNUMBH), logged value of firm age (LNFMAGE), and logged value of CEO age (LNCEOAGE). We calculate ROA as the ratio of operating income after depreciation (item 178) to total assets (item 6). We calculate RET1YR as the cumulative monthly returns over the past twelve months. We estimate BETA from fitting the Capital Asset Pricing Model (CAPM) to a company's monthly stock returns over the past five years. We annualize the standard deviation in daily stock returns over the past one year to obtain VOL1YR. We divide the total number of shares traded (item 28) by the total number of shares outstanding (item 25) and take logs on the ratio to obtain LNSHTURN. We calculate TOBIN as the ratio of the market value of assets to the book value of assets, where the market value of assets equals the book value of assets (item 6) plus the market value of common equity (item 25 times item 199) minus the book value of common equity (item 60) and balance sheet deferred taxes (item 74). If the number of analyst information for a firm is missing, we set the number to zero. We compute INSTHOLD as the ratio of the total number of shares held by all institutions to the total number of shares outstanding. We calculate LNFMAGE as the logarithm value of the number of years since the CRSP begins its coverage of a firm. We use Fama-French's 49-industry classification, and for each of these 49 industries, we sum over the one-year stock returns of all the firms of this industry with equal weights to calculate INDRET. Block holders refer to the institutional investors owning more than $5 \%$ of a company's outstanding shares, and if the blockholding information is missing we set it to zero. 
Panel A. Summary statistics of PIN, FORCETURN, and proxies for cost of firing CEOs

\begin{tabular}{l|cccccccc}
\hline & Nobs & Mean & Std & Min & Max & $1 \%$ & Median & $99 \%$ \\
\hline PIN & 16,726 & 0.150 & 0.072 & 0 & 1 & 0.017 & 0.140 & 0.351 \\
CEOTURN & 16,726 & 0.099 & 0.299 & 0 & 1 & 0 & 0 & 1 \\
FORCETURN & 16,726 & 0.024 & 0.153 & 0 & 1 & 0 & 0 & 1 \\
LNTEN & 16,726 & 1.962 & 0.766 & 0 & 4.111 & 0.693 & 1.946 & 3.664 \\
CEOSH & 16,726 & 0.026 & 0.063 & 0 & 0.642 & 0 & 0.003 & 0.336 \\
DUAL & 16,726 & 0.655 & 0.475 & 0 & 1 & 0 & 1 & 1 \\
POD & 14,504 & 0.790 & 0.120 & 0 & 1 & 0.4 & 0.818 & 0.933 \\
\hline
\end{tabular}

Panel B. Sample correlations

\begin{tabular}{|c|c|c|c|c|c|c|}
\hline & PIN & FORCETURN & LNTEN & CEOSH & DUAL & POD \\
\hline$\overline{\mathrm{PIN}}$ & 1.0000 & & & & & \\
\hline FORCETURN & $\begin{array}{l}0.0092 \\
(0.232)\end{array}$ & 1.0000 & & & & \\
\hline LNTEN & $\begin{array}{l}0.0620 \\
(0.000)\end{array}$ & $\begin{array}{c}-0.1413 \\
(0.000)\end{array}$ & 1.0000 & & & \\
\hline CEOSH & $\begin{array}{l}0.1456 \\
(0.000)\end{array}$ & $\begin{array}{c}-0.0322 \\
(0.000)\end{array}$ & $\begin{array}{l}0.3487 \\
(0.000)\end{array}$ & 1.0000 & & \\
\hline DUAL & $\begin{array}{c}-0.1056 \\
(0.000)\end{array}$ & $\begin{array}{c}-0.0554 \\
(0.000)\end{array}$ & $\begin{array}{l}0.2961 \\
(0.000)\end{array}$ & $\begin{array}{l}0.1191 \\
(0.000)\end{array}$ & 1.0000 & \\
\hline POD & $\begin{array}{c}-0.1497 \\
(0.000)\end{array}$ & $\begin{array}{l}0.0212 \\
(0.011)\end{array}$ & $\begin{array}{c}-0.2197 \\
(0.000)\end{array}$ & $\begin{array}{c}-0.3088 \\
(0.000)\end{array}$ & $\begin{array}{l}0.0465 \\
(0.000)\end{array}$ & 1.0000 \\
\hline
\end{tabular}

Panel C. Summary statistics of control variables

\begin{tabular}{l|cccccccc}
\hline & Nobs & Mean & Std & Min & Max & $1 \%$ & Median & $99 \%$ \\
\hline LNME & 16,726 & 7.390 & 1.636 & 0.642 & 13.299 & 3.668 & 7.298 & 11.537 \\
ROA & 16,726 & 0.084 & 0.129 & -3.076 & 0.930 & -0.353 & 0.085 & 0.348 \\
RET1YR & 16,726 & 0.201 & 0.640 & -0.982 & 14.943 & -0.768 & 0.126 & 2.5 \\
INDRET & 16,726 & 0.264 & 0.313 & -0.594 & 3.262 & -0.306 & 0.224 & 1.404 \\
BETA & 16,726 & 1.061 & 0.745 & -1.919 & 5.800 & -0.110 & 0.926 & 3.557 \\
VOL1YR & 16,726 & 0.428 & 0.232 & 0.096 & 4.261 & 0.144 & 0.368 & 1.209 \\
LNSHTURN & 16,726 & 0.236 & 0.798 & -3.373 & 12.937 & -1.516 & 0.189 & 2.129 \\
TOBIN & 16,726 & 2.018 & 1.885 & 0.360 & 78.565 & 0.746 & 1.474 & 8.961 \\
LNNUMEST & 16,726 & 1.740 & 0.696 & 0 & 3.481 & 0 & 1.778 & 3.080 \\
INSTHOLD & 16,726 & 0.610 & 0.202 & $3.42 \mathrm{e}-3$ & 0.9997 & 0.116 & 0.630 & 0.968 \\
LNNUMBH & 16,726 & 0.927 & 0.500 & 0 & 2.277 & 0 & 1.012 & 1.833 \\
LNFMAGE & 16,726 & 2.943 & 0.782 & 1.099 & 4.407 & 1.386 & 2.996 & 4.369 \\
LNCEOAGE & 16,726 & 4.037 & 0.135 & 3.367 & 4.533 & 3.689 & 4.043 & 4.357 \\
\hline
\end{tabular}


Table 2. Annual Breakdown of PIN, CEO Turnover, and Forced CEO turnover across (Fiscal) Years: 1995-2006

\begin{tabular}{c|c|c|c|c|c|c|c}
\hline \multirow{2}{*}{ year } & \multirow{2}{*}{ Nobs } & \multicolumn{2}{|c|}{ PIN } & \multicolumn{2}{c|}{ CEOTURN } & \multicolumn{2}{c}{ FORCETURN } \\
\cline { 3 - 8 } & & Mean & Std & Mean & Std & Mean & Std \\
\hline 1995 & 1,360 & 0.180 & 0.059 & 0.099 & 0.299 & 0.018 & 0.132 \\
\hline 1996 & 1,407 & 0.179 & 0.065 & 0.092 & 0.290 & 0.020 & 0.140 \\
\hline 1997 & 1,406 & 0.148 & 0.055 & 0.102 & 0.302 & 0.026 & 0.160 \\
\hline 1998 & 1,463 & 0.143 & 0.063 & 0.107 & 0.309 & 0.025 & 0.157 \\
\hline 1999 & 1,489 & 0.151 & 0.100 & 0.109 & 0.312 & 0.021 & 0.145 \\
\hline 2000 & 1,469 & 0.153 & 0.123 & 0.128 & 0.334 & 0.033 & 0.178 \\
\hline 2001 & 1,440 & 0.153 & 0.121 & 0.110 & 0.313 & 0.023 & 0.150 \\
\hline 2002 & 1,415 & 0.136 & 0.102 & 0.100 & 0.301 & 0.035 & 0.185 \\
\hline 2003 & 1,447 & 0.133 & 0.062 & 0.096 & 0.295 & 0.031 & 0.174 \\
\hline 2004 & 1,414 & 0.137 & 0.072 & 0.093 & 0.291 & 0.017 & 0.129 \\
\hline 2005 & 1,408 & 0.137 & 0.080 & 0.099 & 0.299 & 0.022 & 0.147 \\
\hline 2006 & 1,008 & 0.131 & 0.165 & 0.034 & 0.181 & 0.010 & 0.099 \\
\hline
\end{tabular}




\section{Table 3. Estimation of the Reduced-Form PIN Equation}

This table reports the OLS estimation results on the reduced-form PIN equation using data over 19952006. Firms are classified into one of the Fama-French 49 industries. Estimates on the industry dummies and year dummies are suppressed to save space. Robust standard errors adjusted for clustering in firms are reported in parentheses. *, **, and $* * *$ denote (two-sided) significance at the $10 \%, 5 \%$, and $1 \%$ levels, respectively.

\begin{tabular}{|c|c|c|c|c|c|}
\hline & Model (1) & Model (2) & Model (3) & Model (4) & Model (5) \\
\hline INTERCEPT & $\begin{array}{c}0.365 * * * \\
(0.026)\end{array}$ & $\begin{array}{c}0.351 * * * \\
(0.026)\end{array}$ & $\begin{array}{c}0.337 * * * \\
(0.026)\end{array}$ & $\begin{array}{c}0.368 * * * \\
(0.029)\end{array}$ & $\begin{array}{c}0.380 * * * \\
(0.030)\end{array}$ \\
\hline LNME & $\begin{array}{c}-0.016^{* * *} * \\
(0.001)\end{array}$ & $\begin{array}{c}-0.016^{* * *} * \\
(0.001)\end{array}$ & $\begin{array}{c}-0.016^{* * *} \\
(0.001)\end{array}$ & $\begin{array}{c}-0.015^{* * *} * \\
(0.001)\end{array}$ & $\begin{array}{c}-0.015^{* * *} * \\
(0.001)\end{array}$ \\
\hline ROA & $\begin{array}{c}0.011 \\
(0.011)\end{array}$ & $\begin{array}{c}0.010 \\
(0.011)\end{array}$ & $\begin{array}{c}0.012 \\
(0.011)\end{array}$ & $\begin{array}{c}-1.44 \mathrm{e}-4 \\
(0.015)\end{array}$ & $\begin{array}{c}-0.003 \\
(0.015)\end{array}$ \\
\hline RET1YR & $\begin{array}{c}0.004 * * \\
(0.002)\end{array}$ & $\begin{array}{c}0.004 * * * \\
(0.002)\end{array}$ & $\begin{array}{c}0.004 * * \\
(0.002)\end{array}$ & $\begin{array}{c}0.004 * * \\
(0.002)\end{array}$ & $\begin{array}{c}0.004 * * \\
(0.002)\end{array}$ \\
\hline INDRET & $\begin{array}{c}-0.013 * * * \\
(0.002)\end{array}$ & $\begin{array}{c}-0.013 * * * \\
(0.002)\end{array}$ & $\begin{array}{c}-0.013 * * * \\
(0.002)\end{array}$ & $\begin{array}{c}-0.015^{* * *} * \\
(0.003)\end{array}$ & $\begin{array}{c}-0.015 * * * \\
(0.003)\end{array}$ \\
\hline BETA & $\begin{array}{r}2.20 \mathrm{e}-4 \\
(0.002)\end{array}$ & $\begin{array}{l}3.13 \mathrm{e}-4 \\
(0.002)\end{array}$ & $\begin{array}{l}2.71 \mathrm{e}-4 \\
(0.002)\end{array}$ & $\begin{array}{c}0.001 \\
(0.002)\end{array}$ & $\begin{array}{l}9.59 \mathrm{e}-4 \\
(0.002)\end{array}$ \\
\hline VOL1YR & $\begin{array}{c}0.026 * * * \\
(0.008)\end{array}$ & $\begin{array}{c}0.025^{* * * *} \\
(0.008)\end{array}$ & $\begin{array}{c}0.026 * * * \\
(0.008)\end{array}$ & $\begin{array}{c}0.025 * * * \\
(0.010)\end{array}$ & $\begin{array}{c}0.025 * * * \\
(0.010)\end{array}$ \\
\hline LNSHTURN & $\begin{array}{c}-0.012 * * * \\
(0.002)\end{array}$ & $\begin{array}{c}-0.012 * * * \\
(0.002)\end{array}$ & $\begin{array}{c}-0.012 * * * \\
(0.002)\end{array}$ & $\begin{array}{c}-0.009 * * * \\
(0.002)\end{array}$ & $\begin{array}{c}-0.009 * * * \\
(0.002)\end{array}$ \\
\hline TOBIN & $\begin{array}{c}0.003 * * * \\
(0.001)\end{array}$ & $\begin{array}{c}0.003 * * * \\
(0.001)\end{array}$ & $\begin{array}{c}0.003 * * * \\
(0.001)\end{array}$ & $\begin{array}{c}0.005 * * * \\
(0.001)\end{array}$ & $\begin{array}{c}0.005 * * * \\
(0.001)\end{array}$ \\
\hline LNNUMEST & $\begin{array}{c}-0.005^{* * *} \\
(0.002)\end{array}$ & $\begin{array}{c}-0.005^{* *} \\
(0.001)\end{array}$ & $\begin{array}{c}-0.005^{* * *} * \\
(0.002)\end{array}$ & $\begin{array}{c}-0.005^{* * *} \\
(0.002)\end{array}$ & $\begin{array}{c}-0.005^{* * * *} \\
(0.002)\end{array}$ \\
\hline INSTHOLD & $\begin{array}{c}-0.031 * * * \\
(0.007)\end{array}$ & $\begin{array}{c}-0.028 * * * \\
(0.006)\end{array}$ & $\begin{array}{c}-0.032 * * * \\
(0.007)\end{array}$ & $\begin{array}{c}-0.033^{* * *} * \\
(0.007)\end{array}$ & $\begin{array}{c}-0.030 * * * \\
(0.007)\end{array}$ \\
\hline LNNUMBH & $\begin{array}{c}0.007 * * * \\
(0.002)\end{array}$ & $\begin{array}{c}0.007 * * * \\
(0.002)\end{array}$ & $\begin{array}{c}0.007 * * * \\
(0.002)\end{array}$ & $\begin{array}{c}0.005^{* * *} * \\
(0.002)\end{array}$ & $\begin{array}{c}0.005^{* * *} * \\
(0.002)\end{array}$ \\
\hline LNFMAGE & $\begin{array}{c}-0.008 * * * \\
(0.001)\end{array}$ & $\begin{array}{c}-0.007 * * * * \\
(0.001)\end{array}$ & $\begin{array}{c}-0.008 * * * \\
(0.001)\end{array}$ & $\begin{array}{c}-0.007 * * * \\
(0.001)\end{array}$ & $\begin{array}{c}-0.007 * * * \\
(0.001)\end{array}$ \\
\hline LNCEOAGE & $\begin{array}{c}-0.014 * * \\
(0.006)\end{array}$ & $\begin{array}{l}-0.009 \\
(0.006)\end{array}$ & $\begin{array}{l}-0.005 \\
(0.006)\end{array}$ & $\begin{array}{l}-0.012 \\
(0.007)\end{array}$ & $\begin{array}{c}-0.018 * * \\
(0.007)\end{array}$ \\
\hline LNTEN & $\begin{array}{c}0.004 * * * \\
(0.001)\end{array}$ & & & & $\begin{array}{c}0.003 * * * \\
(0.001)\end{array}$ \\
\hline CEOSH & & $\begin{array}{c}0.047 * * * \\
(0.016)\end{array}$ & & & $\begin{array}{c}0.035^{* *} \\
(0.017)\end{array}$ \\
\hline DUAL & & & $\begin{array}{l}-0.002 \\
(0.002)\end{array}$ & & $\begin{array}{l}-0.003 \\
(0.002)\end{array}$ \\
\hline POD & & & & $\begin{array}{c}-0.010 * * * \\
(0.004)\end{array}$ & $\begin{array}{c}-0.006 * * \\
(0.003)\end{array}$ \\
\hline INDUSTRY & Yes & Yes & Yes & Yes & Yes \\
\hline YEAR & Yes & Yes & Yes & Yes & Yes \\
\hline Sample Size & 16,726 & 16,726 & 16,726 & 14,504 & 14,504 \\
\hline $\mathrm{R}^{2}$ & 0.307 & 0.307 & 0.306 & 0.286 & 0.288 \\
\hline
\end{tabular}


Table 4. Estimation of the Reduced-Form FORCETURN Equation: Using Probit Models

This table reports the estimation results from fitting a maximum-likelihood probit model on the reduced-form FORCETURN equation using data over 1995-2006. The dependent variable is FORCETURN, which equals one if the CEO turnover is forced and zero otherwise. Firms are classified into one of the Fama-French 49 industries. Estimates on the industry dummies and year dummies are suppressed to save space. Robust standard errors adjusted for clustering in firms are reported in parentheses. *, **, and *** denote (two-sided) significance at the $10 \%, 5 \%$, and $1 \%$ levels, respectively.

\begin{tabular}{|c|c|c|c|c|c|}
\hline & Model (1) & Model (2) & Model (3) & Model (4) & Model (5) \\
\hline INTERCEPT & $\begin{array}{c}-6.012 * * * \\
(0.862)\end{array}$ & $\begin{array}{c}-4.495 * * * \\
(0.859)\end{array}$ & $\begin{array}{c}-4.980 * * * \\
(0.846)\end{array}$ & $\begin{array}{c}-4.748 * * * \\
(0.945)\end{array}$ & $\begin{array}{c}-6.656^{* * * *} \\
(1.012)\end{array}$ \\
\hline LNME & $\begin{array}{l}-0.032 \\
(0.029)\end{array}$ & $\begin{array}{l}-0.030 \\
(0.028)\end{array}$ & $\begin{array}{l}-0.019 \\
(0.028)\end{array}$ & $\begin{array}{l}-0.048 \\
(0.031)\end{array}$ & $\begin{array}{l}-0.046 \\
(0.031)\end{array}$ \\
\hline ROA & $\begin{array}{c}-0.627 * * * \\
(0.152)\end{array}$ & $\begin{array}{c}-0.640 * * * \\
(0.153)\end{array}$ & $\begin{array}{c}-0.763 * * * \\
(0.155)\end{array}$ & $\begin{array}{c}-0.732 * * * \\
(0.182)\end{array}$ & $\begin{array}{c}-0.637 \text { **** } \\
(0.181)\end{array}$ \\
\hline RET1YR & $\begin{array}{c}-0.795 * * * \\
(0.117)\end{array}$ & $\begin{array}{c}-0.780 * * * \\
(0.117)\end{array}$ & $\begin{array}{c}-0.791 * * * \\
(0.117)\end{array}$ & $\begin{array}{c}-0.703 * * * \\
(0.128)\end{array}$ & $\begin{array}{c}-0.731 * * * \\
(0.127)\end{array}$ \\
\hline INDRET & $\begin{array}{c}0.316^{* * * *} \\
(0.087)\end{array}$ & $\begin{array}{c}0.324 * * * \\
(0.087)\end{array}$ & $\begin{array}{c}0.325^{* * * *} \\
(0.087)\end{array}$ & $\begin{array}{c}0.327 * * * \\
(0.093)\end{array}$ & $\begin{array}{c}0.325 * * * \\
(0.094)\end{array}$ \\
\hline BETA & $\begin{array}{c}0.006 \\
(0.046)\end{array}$ & $\begin{array}{l}-0.010 \\
(0.043)\end{array}$ & $\begin{array}{l}-0.005 \\
(0.044)\end{array}$ & $\begin{array}{c}0.016 \\
(0.050)\end{array}$ & $\begin{array}{c}0.041 \\
(0.052)\end{array}$ \\
\hline VOL1YR & $\begin{array}{c}-0.318 \\
(0.201)\end{array}$ & $\begin{array}{c}-0.234 \\
(0.186)\end{array}$ & $\begin{array}{c}-0.302 \\
(0.194)\end{array}$ & $\begin{array}{l}-0.152 \\
(0.192)\end{array}$ & $\begin{array}{l}-0.213 \\
(0.217)\end{array}$ \\
\hline LNSHTURN & $\begin{array}{c}0.256 * * * \\
(0.045)\end{array}$ & $\begin{array}{c}0.211 * * * \\
(0.041)\end{array}$ & $\begin{array}{c}0.232 * * * \\
(0.042)\end{array}$ & $\begin{array}{c}0.208 * * * \\
(0.046)\end{array}$ & $\begin{array}{c}0.251 * * * \\
(0.051)\end{array}$ \\
\hline TOBIN & $\begin{array}{c}-0.026 \\
(0.022)\end{array}$ & $\begin{array}{c}-0.024 \\
(0.021)\end{array}$ & $\begin{array}{c}-0.031 \\
(0.022)\end{array}$ & $\begin{array}{c}-0.034 \\
(0.025)\end{array}$ & $\begin{array}{l}-0.033 \\
(0.025)\end{array}$ \\
\hline LNNUMEST & $\begin{array}{c}0.090 \\
(0.057)\end{array}$ & $\begin{array}{c}0.087 \\
(0.056)\end{array}$ & $\begin{array}{c}0.112 * * \\
(0.055)\end{array}$ & $\begin{array}{l}0.108^{*} \\
(0.064)\end{array}$ & $\begin{array}{l}0.115^{*} \\
(0.065)\end{array}$ \\
\hline INSTHOLD & $\begin{array}{c}-0.849 * * * \\
(0.203)\end{array}$ & $\begin{array}{c}-1.043 * * * \\
(0.191)\end{array}$ & $\begin{array}{c}-0.870 * * * \\
(0.196)\end{array}$ & $\begin{array}{c}-0.892 * * * \\
(0.212)\end{array}$ & $\begin{array}{c}-0.861 * * * \\
(0.222)\end{array}$ \\
\hline LNNUMBH & $\begin{array}{c}0.176^{* * * *} \\
(0.070)\end{array}$ & $\begin{array}{c}0.207 * * * \\
(0.065)\end{array}$ & $\begin{array}{c}0.199 * * * \\
(0.066)\end{array}$ & $\begin{array}{c}0.200 * * * \\
(0.070)\end{array}$ & $\begin{array}{c}0.192 * * \\
(0.076)\end{array}$ \\
\hline LNFMAGE & $\begin{array}{c}-0.034 \\
(0.035)\end{array}$ & $\begin{array}{c}-0.029 \\
(0.037)\end{array}$ & $\begin{array}{c}0.011 \\
(0.039)\end{array}$ & $\begin{array}{l}-0.023 \\
(0.042)\end{array}$ & $\begin{array}{l}-0.035 \\
(0.041)\end{array}$ \\
\hline LNCEOAGE & $\begin{array}{c}1.336^{* * * *} \\
(0.206)\end{array}$ & $\begin{array}{c}0.728 * * * \\
(0.206)\end{array}$ & $\begin{array}{c}0.823 * * * \\
(0.200)\end{array}$ & $\begin{array}{c}0.559 * * * \\
(0.215)\end{array}$ & $\begin{array}{c}1.372 * * * \\
(0.235)\end{array}$ \\
\hline LNTEN & $\begin{array}{c}-0.596 * * * \\
(0.041)\end{array}$ & & & & $\begin{array}{c}-0.579 * * * \\
(0.049)\end{array}$ \\
\hline CEOSH & & $\begin{array}{c}-2.958 * * * \\
(1.097)\end{array}$ & & & $\begin{array}{c}-0.244 \\
(0.779)\end{array}$ \\
\hline DUAL & & & $\begin{array}{c}-0.327 * * * \\
(0.052)\end{array}$ & & $\begin{array}{c}-0.091 \\
(0.059)\end{array}$ \\
\hline POD & & & & $\begin{array}{c}1.098 * * * \\
(0.246)\end{array}$ & $\begin{array}{c}0.718 * * * \\
(0.265)\end{array}$ \\
\hline INDUSTRY & Yes & Yes & Yes & Yes & Yes \\
\hline $\begin{array}{l}\text { YEAR } \\
\text { Sample Size }\end{array}$ & $\begin{array}{c}\text { Yes } \\
16,726\end{array}$ & $\begin{array}{c}\text { Yes } \\
16,726\end{array}$ & $\begin{array}{c}\text { Yes } \\
16,726\end{array}$ & $\begin{array}{c}\text { Yes } \\
14,504\end{array}$ & $\begin{array}{c}\text { Yes } \\
14,504\end{array}$ \\
\hline Pseudo $\mathrm{R}^{2}$ & 0.228 & 0.148 & 0.151 & 0.141 & 0.227 \\
\hline Loglikelihood & $-1,455.18$ & $-1,605.12$ & $-1,599.52$ & $-1,375.46$ & $-1,237.03$ \\
\hline
\end{tabular}


Table 5. Estimation of the Reduced-Form FORCETURN Equation: Bivariate Probit Models This table reports the estimation results from applying a maximum-likelihood bivariate probit model to the reduced-form FORCETURN equation. The dependent variable is FORCETURN, which equals one if the CEO turnover is forced and zero otherwise. The reported coefficient estimates are for regressions that are jointly estimated with the CEOTURN equation in which the dependent variable equals one if there is CEO turnover and zero otherwise. The CEOTURN relation in all models is the same as the FORCETURN equation, and its estimation results are suppressed for brevity. The sample period is 1995-2006. Firms are classified into one of the Fama-French 49 industries. Estimates on the industry dummies and year dummies are suppressed to save space. Robust standard errors adjusted for clustering in firms are reported in parentheses. *,**, and *** denote (two-sided) significance at the $10 \%, 5 \%$, and $1 \%$ levels, respectively.

\begin{tabular}{|c|c|c|c|c|c|}
\hline & Model (1) & Model (2) & Model (3) & Model (4) & Model (5) \\
\hline INTERCEPT & $\begin{array}{c}-7.943 * * * \\
(0.792)\end{array}$ & $\begin{array}{c}-5.244 * * * \\
(0.800)\end{array}$ & $\begin{array}{c}-5.896 * * * \\
(0.812)\end{array}$ & $\begin{array}{c}-5.055^{*} * * \\
(0.907)\end{array}$ & $\begin{array}{c}-8.407 * * * * \\
(0.986)\end{array}$ \\
\hline LNME & $\begin{array}{l}-0.012 \\
(0.024)\end{array}$ & $\begin{array}{l}-0.007 \\
(0.026)\end{array}$ & $\begin{array}{c}0.007 \\
(0.026)\end{array}$ & $\begin{array}{l}-0.022 \\
(0.029)\end{array}$ & $\begin{array}{l}-0.025 \\
(0.027)\end{array}$ \\
\hline ROA & $\begin{array}{c}-0.611 * * * \\
(0.113)\end{array}$ & $\begin{array}{c}-0.636 * * * \\
(0.152)\end{array}$ & $\begin{array}{c}-0.800 * * * \\
(0.134)\end{array}$ & $\begin{array}{c}-0.617 * * * \\
(0.171)\end{array}$ & $\begin{array}{c}-0.540 * * * \\
(0.179)\end{array}$ \\
\hline RET1YR & $\begin{array}{c}-0.695 * * * \\
(0.093)\end{array}$ & $\begin{array}{c}-0.682 * * * \\
(0.096)\end{array}$ & $\begin{array}{c}-0.681 * * * \\
(0.099)\end{array}$ & $\begin{array}{c}-0.644 * * * \\
(0.113)\end{array}$ & $\begin{array}{c}-0.670 * * * \\
(0.099)\end{array}$ \\
\hline INDRET & $\begin{array}{c}0.293 * * * \\
(0.085)\end{array}$ & $\begin{array}{c}0.311 * * * \\
(0.082)\end{array}$ & $\begin{array}{c}0.304 * * * \\
(0.081)\end{array}$ & $\begin{array}{c}0.315 * * * \\
(0.090)\end{array}$ & $\begin{array}{c}0.325 * * * \\
(0.089)\end{array}$ \\
\hline BETA & $\begin{array}{c}0.013 \\
(0.051)\end{array}$ & $\begin{array}{c}0.008 \\
(0.046)\end{array}$ & $\begin{array}{c}0.010 \\
(0.048)\end{array}$ & $\begin{array}{c}0.046 \\
(0.053)\end{array}$ & $\begin{array}{c}0.049 \\
(0.056)\end{array}$ \\
\hline VOL1YR & $\begin{array}{c}-0.231 \\
(0.189)\end{array}$ & $\begin{array}{l}-0.145 \\
(0.202)\end{array}$ & $\begin{array}{l}-0.228 \\
(0.206)\end{array}$ & $\begin{array}{l}-0.051 \\
(0.187)\end{array}$ & $\begin{array}{l}-0.090 \\
(0.202)\end{array}$ \\
\hline LNSHTURN & $\begin{array}{c}0.271 * * * \\
(0.033)\end{array}$ & $\begin{array}{c}0.222 * * * \\
(0.042)\end{array}$ & $\begin{array}{c}0.245^{* * *} \\
(0.042)\end{array}$ & $\begin{array}{c}0.211 * * * \\
(0.050)\end{array}$ & $\begin{array}{c}0.254 * * * \\
(0.037)\end{array}$ \\
\hline TOBIN & $\begin{array}{l}-0.038 \\
(0.024)\end{array}$ & $\begin{array}{l}-0.037 \\
(0.024)\end{array}$ & $\begin{array}{c}-0.043^{*} \\
(0.022)\end{array}$ & $\begin{array}{l}-0.043 \\
(0.028)\end{array}$ & $\begin{array}{l}-0.041 \\
(0.031)\end{array}$ \\
\hline LNNUMEST & $\begin{array}{c}0.071 \\
(0.055)\end{array}$ & $\begin{array}{c}0.065 \\
(0.051)\end{array}$ & $\begin{array}{l}0.094 * \\
(0.051)\end{array}$ & $\begin{array}{l}0.091^{*} \\
(0.054)\end{array}$ & $\begin{array}{l}0.101^{*} \\
(0.061)\end{array}$ \\
\hline INSTHOLD & $\begin{array}{c}-0.763 * * * \\
(0.188)\end{array}$ & $\begin{array}{c}-0.929 * * * \\
(0.187)\end{array}$ & $\begin{array}{c}-0.733 * * * \\
(0.192)\end{array}$ & $\begin{array}{c}-0.789 * * * \\
(0.196)\end{array}$ & $\begin{array}{c}-0.789 * * * \\
(0.211)\end{array}$ \\
\hline LNNUMBH & $\begin{array}{c}0.143 * * \\
(0.071)\end{array}$ & $\begin{array}{c}0.180 * * * \\
(0.065)\end{array}$ & $\begin{array}{c}0.175^{* * *} * \\
(0.066)\end{array}$ & $\begin{array}{c}0.181 * * * \\
(0.068)\end{array}$ & $\begin{array}{c}0.167 * * \\
(0.074)\end{array}$ \\
\hline LNFMAGE & $\begin{array}{c}-0.018 \\
(0.037)\end{array}$ & $\begin{array}{l}-0.017 \\
(0.038)\end{array}$ & $\begin{array}{c}0.015 \\
(0.039)\end{array}$ & $\begin{array}{l}-0.012 \\
(0.040)\end{array}$ & $\begin{array}{l}-0.015 \\
(0.042)\end{array}$ \\
\hline LNCEOAGE & $\begin{array}{c}1.750 * * * \\
(0.177)\end{array}$ & $\begin{array}{c}0.868 * * * \\
(0.180)\end{array}$ & $\begin{array}{c}1.008 * * * \\
(0.185)\end{array}$ & $\begin{array}{c}0.603 * * * \\
(0.195)\end{array}$ & $\begin{array}{c}1.737 * * * \\
(0.217)\end{array}$ \\
\hline LNTEN & $\begin{array}{c}-0.532 * * * \\
(0.028)\end{array}$ & & & & $\begin{array}{c}-0.503 * * * \\
(0.040)\end{array}$ \\
\hline CEOSH & & $\begin{array}{c}-2.719 * * * \\
(0.735)\end{array}$ & & & $\begin{array}{l}-0.200 \\
(0.802)\end{array}$ \\
\hline DUAL & & & $\begin{array}{c}-0.356 * * * \\
(0.052)\end{array}$ & & $\begin{array}{c}-0.136 * * \\
(0.066)\end{array}$ \\
\hline POD & & & & $\begin{array}{c}1.016 * * * \\
(0.252)\end{array}$ & $\begin{array}{c}0.702 * * * \\
(0.281)\end{array}$ \\
\hline INDUSTRY & Yes & Yes & Yes & Yes & Yes \\
\hline YEAR & Yes & Yes & Yes & Yes & Yes \\
\hline Sample Size & 16,726 & 16,726 & 16,726 & 14,504 & 14,504 \\
\hline Loglikelihood & $-1,455.18$ & $-1,605.12$ & $-1,599.52$ & $-1,375.46$ & $-1,237.03$ \\
\hline
\end{tabular}




\section{Table 6. Estimation of the Structural System: the PIN Equation}

This table reports the maximum likelihood estimates on the PIN equation in the structural system. The dependent variable of interest is PIN, and the endogenous variable on the right hand-side of this equation is FORCETURN. The FORCETURN relation follows a reduced-form probit model specification:

$\operatorname{Prob}(F O R C E T U R N)=\lambda_{0}+\lambda_{1} * L N M E+\lambda_{2} * R O A+\lambda_{3} * R E T 1 Y R+\lambda_{4} * I N D R E T+\lambda_{5} * B E T A$

$+\lambda_{6} *$ VOLIYR $+\lambda_{7} *$ LNSHTURN $+\lambda_{8} *$ TOBIN $+\lambda_{9} *$ LNNUMEST $+\lambda_{10} *$ INSTOHOLD

$+\lambda_{11} * L N N U M B H+\lambda_{12} * L N F M A G E+\lambda_{13} * L N C E O A G E+\lambda_{14} * P R O X Y \_F I R E+I N D U S T R Y / Y E A R$, where PROXY_FIRE represents the cost of firing a CEO. The proxy is LNTEN, CEOSH, DUAL, and POD in Models (1), (2), (3) and (4), respectively, and the four proxies are jointly used in Model (5). Estimation results on the FORCETURN relation are suppressed for brevity. The sample period is 1995-2006. Firms are classified into one of the Fama-French 49 industries. Estimates on the industry dummies and year dummies are not reported. Robust standard errors adjusted for clustering in firms are reported in parentheses. *, **, and $* * *$ denote (two-sided) significance at the $10 \%, 5 \%$, and $1 \%$ levels, respectively. The p-value is for the Wald test on the independence of the two equations.

\begin{tabular}{|c|c|c|c|c|c|}
\hline & Model (1) & Model (2) & Model (3) & Model (4) & Model (5) \\
\hline INTERCEPT & $\begin{array}{c}0.317 * * * \\
(0.009)\end{array}$ & $\begin{array}{c}0.317 * * * \\
(0.009)\end{array}$ & $\begin{array}{c}0.317 * * * \\
(0.009)\end{array}$ & $\begin{array}{c}0.314 * * * \\
(0.010)\end{array}$ & $\begin{array}{c}0.314 * * * \\
(0.010)\end{array}$ \\
\hline FORCETURN & $\begin{array}{c}-0.011 * * * \\
(0.004)\end{array}$ & $\begin{array}{c}-0.009 * * \\
(0.004)\end{array}$ & $\begin{array}{c}-0.011 * * * \\
(0.004)\end{array}$ & $\begin{array}{c}-0.011 * * \\
(0.004)\end{array}$ & $\begin{array}{c}-0.012 * * * \\
(0.005)\end{array}$ \\
\hline LNME & $\begin{array}{c}-0.016 * * * \\
(0.001)\end{array}$ & $\begin{array}{c}-0.016 * * * \\
(0.001)\end{array}$ & $\begin{array}{c}-0.016^{* * *} * \\
(0.001)\end{array}$ & $\begin{array}{c}-0.016 * * * \\
(0.001)\end{array}$ & $\begin{array}{c}-0.016 * * * \\
(0.001)\end{array}$ \\
\hline ROA & $\begin{array}{c}0.011 \\
(0.011)\end{array}$ & $\begin{array}{c}0.011 \\
(0.011)\end{array}$ & $\begin{array}{c}0.011 \\
(0.011)\end{array}$ & $\begin{array}{c}-6.15 \mathrm{e}-4 \\
(0.015)\end{array}$ & $\begin{array}{c}-7.71 \mathrm{e}-4 \\
(0.015)\end{array}$ \\
\hline RET1YR & $\begin{array}{c}0.002 \\
(0.002)\end{array}$ & $\begin{array}{c}0.002 \\
(0.002)\end{array}$ & $\begin{array}{c}0.002 \\
(0.002)\end{array}$ & $\begin{array}{c}0.002 \\
(0.002)\end{array}$ & $\begin{array}{c}0.002 \\
(0.002)\end{array}$ \\
\hline BETA & $\begin{array}{r}4.84 \mathrm{e}-4 \\
(0.002)\end{array}$ & $\begin{array}{l}4.92 \mathrm{e}-4 \\
(0.002)\end{array}$ & $\begin{array}{c}4.88 \mathrm{e}-4 \\
(0.002)\end{array}$ & $\begin{array}{c}0.001 \\
(0.002)\end{array}$ & $\begin{array}{c}0.001 \\
(0.002)\end{array}$ \\
\hline VOL1YR & $\begin{array}{c}0.028 * * * \\
(0.008)\end{array}$ & $\begin{array}{c}0.028 * * * \\
(0.008)\end{array}$ & $\begin{array}{c}0.028 * * * \\
(0.008)\end{array}$ & $\begin{array}{c}0.028 * * * \\
(0.010)\end{array}$ & $\begin{array}{c}0.028 * * * \\
(0.010)\end{array}$ \\
\hline LNSHTURN & $\begin{array}{c}-0.012 * * * \\
(0.002)\end{array}$ & $\begin{array}{c}-0.012 * * * \\
(0.002)\end{array}$ & $\begin{array}{c}-0.012 * * * \\
(0.002)\end{array}$ & $\begin{array}{c}-0.010 * * * \\
(0.002)\end{array}$ & $\begin{array}{c}-0.010 * * * \\
(0.002)\end{array}$ \\
\hline TOBIN & $\begin{array}{c}0.003 * * * \\
(0.001)\end{array}$ & $\begin{array}{c}0.003 * * * \\
(0.001)\end{array}$ & $\begin{array}{c}0.003 * * * \\
(0.001)\end{array}$ & $\begin{array}{c}0.005 * * * \\
(0.001)\end{array}$ & $\begin{array}{c}0.005 * * * \\
(0.001)\end{array}$ \\
\hline LNNUMEST & $\begin{array}{c}-0.006 * * * \\
(0.002)\end{array}$ & $\begin{array}{c}-0.006 * * * \\
(0.002)\end{array}$ & $\begin{array}{c}-0.006 * * * \\
(0.002)\end{array}$ & $\begin{array}{c}-0.006 * * * \\
(0.002)\end{array}$ & $\begin{array}{c}-0.006 * * \\
(0.002)\end{array}$ \\
\hline INSTHOLD & $\begin{array}{c}-0.019 * * * \\
(0.006)\end{array}$ & $\begin{array}{c}-0.018 * * * \\
(0.006)\end{array}$ & $\begin{array}{c}-0.018 * * * \\
(0.006)\end{array}$ & $\begin{array}{c}-0.025 * * * \\
(0.007)\end{array}$ & $\begin{array}{c}-0.025^{* * *} * \\
(0.007)\end{array}$ \\
\hline LNFMAGE & $\begin{array}{c}-0.008 * * * \\
(0.001)\end{array}$ & $\begin{array}{c}-0.008 * * * \\
(0.001)\end{array}$ & $\begin{array}{c}-0.008 * * * \\
(0.001)\end{array}$ & $\begin{array}{c}-0.008 * * * \\
(0.001)\end{array}$ & $\begin{array}{c}-0.008 * * * \\
(0.001)\end{array}$ \\
\hline INDUSTRY & Yes & Yes & Yes & Yes & Yes \\
\hline $\begin{array}{l}\text { YEAR } \\
\text { P-value }\end{array}$ & $\begin{array}{c}\text { Yes } \\
0.081\end{array}$ & $\begin{array}{c}\text { Yes } \\
0.237\end{array}$ & $\begin{array}{c}\text { Yes } \\
0.031\end{array}$ & $\begin{array}{c}\text { Yes } \\
0.088\end{array}$ & $\begin{array}{c}\text { Yes } \\
0.077\end{array}$ \\
\hline Sample Size & 16,726 & 16,726 & 16,726 & 14,504 & 14,504 \\
\hline Loglikelihood & $21,860.54$ & $21,704.19$ & $21,706.86$ & $18,573.57$ & $18,715.93$ \\
\hline
\end{tabular}




\section{Table 7. Estimation of the Structural System: the FORCETURN Equation}

This table reports the maximum likelihood estimates on the FORCETURN equation in the structural system. The dependent variable of interest is FORCETURN, and the endogenous variable on the right hand-side of this equation is PIN. The reduced-form PIN relation is specified as follows:

$$
\begin{aligned}
& \text { PIN }=\pi_{0}+\pi_{1} * \text { LNME }+\pi_{2}^{*} \text { ROA }+\pi_{3}^{*} \text { RETIYR }+\pi_{4}^{*} \text { INDRET }+\pi_{5}^{*} \text { BETA }+\pi_{6}^{*} \text { VOLIYR } \\
& \quad+\pi_{7}^{*} \text { LNSHTURN }+\pi_{8}^{*} \text { TOBIN }+\pi_{9} * \text { LNNUMEST }+\pi_{10} * I N S T H O L D+\pi_{11} * \text { LNNUMBH } \\
& \quad+\pi_{12} * \text { LNFMAGE }+\pi_{13} * \text { LNCEOAGE }+\pi_{14} * \text { PROXY_FIRE }+ \text { INDUSTRY/YEAR DUMMIES, }
\end{aligned}
$$

where PROXY_FIRE represents the cost of firing a CEO. The proxy is LNTEN, CEOSH, DUAL, and POD in Models (1), (2), (3) and (4), respectively, and the four proxies are jointly used in Model (5). Estimation results on the PIN relation are suppressed for brevity. The sample period is 1995-2006. Firms are classified into one of the Fama-French 49 industries. Estimates on the industry dummies and year dummies are not reported. Robust standard errors adjusted for clustering in firms are reported in parentheses. *, **, and $* * *$ denote (two-sided) significance at the $10 \%, 5 \%$, and $1 \%$ levels, respectively. The p-value is for the Wald test of exogeneity, whereas the null hypothesis is that PIN is

\begin{tabular}{|c|c|c|c|c|c|}
\hline & Model (1) & Model (2) & Model (3) & Model (4) & Model (5) \\
\hline INTERCEPT & $\begin{array}{c}-7.976^{* * *} \\
(1.077)\end{array}$ & $\begin{array}{c}-6.773 * * * \\
(1.152)\end{array}$ & $\begin{array}{c}-6.236 * * * \\
(1.257)\end{array}$ & $\begin{array}{c}-7.066 \text { *** } \\
(1.163)\end{array}$ & $\begin{array}{c}-8.969 * * * \\
(1.069)\end{array}$ \\
\hline PIN & $\begin{array}{c}5.216^{* *} \\
(2.187)\end{array}$ & $\begin{array}{c}6.600 * * \\
(3.157)\end{array}$ & $\begin{array}{c}2.965 \\
(3.189)\end{array}$ & $\begin{array}{c}6.878 * * \\
(2.967)\end{array}$ & $\begin{array}{c}\text { 7.484*** } \\
(2.990)\end{array}$ \\
\hline LNME & $\begin{array}{c}0.049 \\
(0.064)\end{array}$ & $\begin{array}{c}0.072 \\
(0.071)\end{array}$ & $\begin{array}{c}0.025 \\
(0.069)\end{array}$ & $\begin{array}{c}0.066 \\
(0.070)\end{array}$ & $\begin{array}{c}0.076 \\
(0.069)\end{array}$ \\
\hline ROA & $\begin{array}{c}-0.617 * * * \\
(0.143)\end{array}$ & $\begin{array}{c}-0.645 * * * \\
(0.153)\end{array}$ & $\begin{array}{c}-0.784 * * * \\
(0.145)\end{array}$ & $\begin{array}{c}-0.667 * * * \\
(0.205)\end{array}$ & $\begin{array}{c}-0.540 * * * \\
(0.212)\end{array}$ \\
\hline RET1YR & $\begin{array}{c}-0.770 * * * \\
(0.113)\end{array}$ & $\begin{array}{c}-0.736^{* * * *} \\
(0.117)\end{array}$ & $\begin{array}{c}-0.784 * * * \\
(0.114)\end{array}$ & $\begin{array}{c}-0.659 * * * \\
(0.122)\end{array}$ & $\begin{array}{c}-0.675 * * * \\
(0.122)\end{array}$ \\
\hline INDRET & $\begin{array}{c}0.394 * * * \\
(0.087)\end{array}$ & $\begin{array}{c}0.412 * * * \\
(0.083)\end{array}$ & $\begin{array}{c}0.385 * * * \\
(0.093)\end{array}$ & $\begin{array}{c}0.411^{* * *} * \\
(0.088)\end{array}$ & $\begin{array}{c}0.413 * * * \\
(0.087)\end{array}$ \\
\hline LNSHTURN & $\begin{array}{c}0.229 * * * \\
(0.040)\end{array}$ & $\begin{array}{c}0.187 * * * \\
(0.040)\end{array}$ & $\begin{array}{c}0.181 * * * \\
(0.043)\end{array}$ & $\begin{array}{c}0.189 * * * \\
(0.039)\end{array}$ & $\begin{array}{c}0.230 * * * \\
(0.039)\end{array}$ \\
\hline TOBIN & $\begin{array}{c}-0.043 * \\
(0.023)\end{array}$ & $\begin{array}{c}-0.045^{*} \\
(0.022)\end{array}$ & $\begin{array}{c}-0.041^{*} \\
(0.025)\end{array}$ & $\begin{array}{c}-0.066 * * \\
(0.026)\end{array}$ & $\begin{array}{c}-0.066 * * * \\
(0.026)\end{array}$ \\
\hline LNNUMEST & $\begin{array}{l}0.091^{*} \\
(0.053)\end{array}$ & $\begin{array}{l}0.084^{*} \\
(0.052)\end{array}$ & $\begin{array}{l}0.095^{*} \\
(0.054)\end{array}$ & $\begin{array}{l}0.112^{*} \\
(0.058)\end{array}$ & $\begin{array}{c}0.122 * * \\
(0.058)\end{array}$ \\
\hline LNNUMBH & $\begin{array}{l}-0.011 \\
(0.050)\end{array}$ & $\begin{array}{l}-0.025 \\
(0.047)\end{array}$ & $\begin{array}{c}0.004 \\
(0.050)\end{array}$ & $\begin{array}{c}0.020 \\
(0.051)\end{array}$ & $\begin{array}{c}0.017 \\
(0.052)\end{array}$ \\
\hline LNCEOAGE & $\begin{array}{c}1.357 * * * \\
(0.201)\end{array}$ & $\begin{array}{c}0.748 * * * \\
(0.192)\end{array}$ & $\begin{array}{c}0.847 * * * \\
(0.198)\end{array}$ & $\begin{array}{c}0.605 * * * \\
(0.202)\end{array}$ & $\begin{array}{c}1.357 * * * \\
(0.228)\end{array}$ \\
\hline LNTEN & $\begin{array}{c}-0.585 * * * \\
(0.045)\end{array}$ & & & & $\begin{array}{c}-0.539 * * * \\
(0.062)\end{array}$ \\
\hline CEOSH & & $\begin{array}{c}-2.846 * * * \\
(0.997)\end{array}$ & & & $\begin{array}{l}-0.396 \\
(0.722)\end{array}$ \\
\hline DUAL & & & $\begin{array}{c}-0.308 * * * \\
(0.055)\end{array}$ & & $\begin{array}{l}-0.051 \\
(0.059)\end{array}$ \\
\hline POD & & & & $\begin{array}{c}1.047 * * * \\
(0.226)\end{array}$ & $\begin{array}{c}0.639 * * * \\
(0.242)\end{array}$ \\
\hline INDUSTRY & Yes & Yes & Yes & Yes & Yes \\
\hline YEAR & Yes & Yes & Yes & Yes & Yes \\
\hline P-value & 0.065 & 0.049 & 0.287 & 0.031 & 0.027 \\
\hline Sample Size & 16,726 & 16,726 & 16,726 & 14,504 & 14,504 \\
\hline Loglikelihood & $21,927.28$ & $21,775.24$ & $21,766.84$ & $18,625.26$ & $18,787.69$ \\
\hline
\end{tabular}
exogenous to the structural FORCETURN equation, i.e, the error term in the structural FORCETURN equation and the error term in the reduced-form PIN equation are uncorrelated. 


\section{Table 8. Joint Estimation of the Structural System}

This table reports the joint estimation results for the structural system of simultaneous equations using the Generalized Least Square method proposed by Amemiya (1979). Eqn1 and Eqn2 refer to the structural equations for PIN and FORCETURN, respectively. The sample period is 1995-2006. Firms are classified into one of the Fama-French 49 industries. Estimates on the industry dummies and year dummies are not reported. Standard errors are reported in parentheses. *, **, and *** denote (two-sided) significance at the $10 \%, 5 \%$, and $1 \%$ levels, respectively.

\begin{tabular}{|c|c|c|c|c|c|c|c|c|c|c|}
\hline & Eqn1 & Eqn2 & Eqn1 & Eqn2 & Eqn1 & Eqn2 & Eqn1 & Eqn2 & Eqn1 & Eqn2 \\
\hline INTERCEPT & $\begin{array}{c}0.299 * * * \\
(0.006)\end{array}$ & $\begin{array}{c}-8.361 * * * \\
(1.438)\end{array}$ & $\begin{array}{c}0.289 * * * \\
(0.008)\end{array}$ & $\begin{array}{c}-7.721^{* *} \\
(1.458)\end{array}$ & $\begin{array}{c}0.310 * * * \\
(0.007)\end{array}$ & $\begin{array}{c}-6.342 * * * \\
(1.314)\end{array}$ & $\begin{array}{c}0.292 * * * * \\
(0.008)\end{array}$ & $\begin{array}{c}-7.671 * * * \\
(1.535)\end{array}$ & $\begin{array}{c}0.298 * * * \\
(0.007)\end{array}$ & $\begin{array}{c}-9.986 * * * \\
(1.720)\end{array}$ \\
\hline PIN & & $\begin{array}{l}5.386^{*} \\
(3.003)\end{array}$ & & $\begin{array}{c}6.878 * * \\
(3.143)\end{array}$ & & $\begin{array}{c}3.009 \\
(2.877)\end{array}$ & & $\begin{array}{c}7.193 * * \\
(3.085)\end{array}$ & & $\begin{array}{c}8.093 * * \\
(3.567)\end{array}$ \\
\hline FORCETURN & $\begin{array}{c}-0.007 * * * \\
(0.001)\end{array}$ & & $\begin{array}{c}-0.014 * * * \\
(0.003)\end{array}$ & & $\begin{array}{c}-7.55 e-4 \\
(0.003)\end{array}$ & & $\begin{array}{c}-0.010 * * * \\
(0.003)\end{array}$ & & $\begin{array}{c}-0.006 * * * \\
(0.001)\end{array}$ & \\
\hline LNME & $\begin{array}{c}-0.016 * * * \\
(0.001)\end{array}$ & $\begin{array}{c}0.050 \\
(0.062)\end{array}$ & $\begin{array}{c}-0.017 * * * \\
(0.001)\end{array}$ & $\begin{array}{c}0.073 \\
(0.064)\end{array}$ & $\begin{array}{c}-0.016 * * * \\
(0.001)\end{array}$ & $\begin{array}{c}0.025 \\
(0.059)\end{array}$ & $\begin{array}{c}-0.017 * * * \\
(0.001)\end{array}$ & $\begin{array}{c}0.064 \\
(0.064)\end{array}$ & $\begin{array}{c}-0.016 * * * \\
(0.001)\end{array}$ & $\begin{array}{c}0.080 \\
(0.071)\end{array}$ \\
\hline ROA & $\begin{array}{c}0.006 \\
(0.005)\end{array}$ & $\begin{array}{c}-0.658 * * * \\
(0.159)\end{array}$ & $\begin{array}{l}2.22 \mathrm{e}-5 \\
(0.005)\end{array}$ & $\begin{array}{c}-0.711 * * * \\
(0.159)\end{array}$ & $\begin{array}{c}0.011^{* *} \\
(0.005)\end{array}$ & $\begin{array}{c}-0.804 * * * \\
(0.152)\end{array}$ & $\begin{array}{l}-0.009 \\
(0.006)\end{array}$ & $\begin{array}{c}-0.759 * * * \\
(0.193)\end{array}$ & $\begin{array}{l}-0.006 \\
(0.006)\end{array}$ & $\begin{array}{c}-0.630 * * * \\
(0.207)\end{array}$ \\
\hline RET1YR & $\begin{array}{l}-0.003^{*} \\
(0.002)\end{array}$ & $\begin{array}{c}-0.816^{* * *} \\
(0.081)\end{array}$ & $\begin{array}{c}-0.008^{* * *} \\
(0.003)\end{array}$ & $\begin{array}{c}-0.808 * * * \\
(0.078)\end{array}$ & $\begin{array}{c}0.002 \\
(0.002)\end{array}$ & $\begin{array}{c}-0.801 * * * \\
(0.078)\end{array}$ & $\begin{array}{l}-0.005^{*} \\
(0.002)\end{array}$ & $\begin{array}{c}-0.732 * * * \\
(0.083)\end{array}$ & $\begin{array}{l}-0.002 \\
(0.002)\end{array}$ & $\begin{array}{c}-0.765 * * * \\
(0.088)\end{array}$ \\
\hline INDRET & & $\begin{array}{c}0.413 * * * \\
(0.102)\end{array}$ & & $\begin{array}{c}0.445^{* * * *} \\
(0.103)\end{array}$ & & $\begin{array}{c}0.390 * * * \\
(0.099)\end{array}$ & & $\begin{array}{c}0.449 * * * \\
(0.110)\end{array}$ & & $\begin{array}{c}0.461 * * * \\
(0.116)\end{array}$ \\
\hline BETA & $\begin{array}{c}4.37 \mathrm{e}-4 \\
(0.001)\end{array}$ & & $\begin{array}{l}3.24 \mathrm{e}-4 \\
(0.001)\end{array}$ & & $\begin{array}{l}5.33 \mathrm{e}-4 \\
(0.001)\end{array}$ & & $\begin{array}{c}0.001 \\
(0.001)\end{array}$ & & $\begin{array}{c}0.001 \\
(0.001)\end{array}$ & \\
\hline VOL1YR & $\begin{array}{c}0.026^{* * * *} \\
(0.005)\end{array}$ & & $\begin{array}{c}0.023 * * * \\
(0.005)\end{array}$ & & $\begin{array}{c}0.028 * * * \\
(0.004)\end{array}$ & & $\begin{array}{c}0.026 * * * \\
(0.005)\end{array}$ & & $\begin{array}{c}0.027 * * * \\
(0.005)\end{array}$ & \\
\hline LNSHTURN & $\begin{array}{c}-0.008 * * * \\
(0.001)\end{array}$ & $\begin{array}{c}0.237 * * * \\
(0.049)\end{array}$ & $\begin{array}{c}-0.010 * * * \\
(0.001)\end{array}$ & $\begin{array}{c}0.198 * * * \\
(0.048)\end{array}$ & $\begin{array}{c}-0.012 * * * \\
(0.001)\end{array}$ & $\begin{array}{c}0.180^{* * * *} \\
(0.046)\end{array}$ & $\begin{array}{c}-0.008 * * * \\
(0.001)\end{array}$ & $\begin{array}{c}0.204 * * * \\
(0.047)\end{array}$ & $\begin{array}{c}-0.009 * * * \\
(0.001)\end{array}$ & $\begin{array}{c}0.255^{* * * *} \\
(0.051)\end{array}$ \\
\hline
\end{tabular}




\begin{tabular}{|c|c|c|c|c|c|c|c|c|c|c|}
\hline TOBIN & $\begin{array}{l}0.003 * * * \\
(3.83 \mathrm{e}-4)\end{array}$ & $\begin{array}{l}-0.046^{*} \\
(0.025)\end{array}$ & $\begin{array}{l}0.003 * * * \\
(4.47 \mathrm{e}-4)\end{array}$ & $\begin{array}{c}-0.049 * * \\
(0.024)\end{array}$ & $\begin{array}{l}0.003 * * * \\
(3.41 \mathrm{e}-4)\end{array}$ & $\begin{array}{l}-0.044 * \\
(0.024)\end{array}$ & $\begin{array}{l}0.005 * * * \\
(4.46 \mathrm{e}-4)\end{array}$ & $\begin{array}{c}-0.072 * * \\
(0.029)\end{array}$ & $\begin{array}{l}0.005 * * * \\
(4.84 \mathrm{e}-4)\end{array}$ & $\begin{array}{c}-0.074 * * \\
(0.032)\end{array}$ \\
\hline LNNUMEST & $\begin{array}{c}-0.005 * * * \\
(0.001)\end{array}$ & $\begin{array}{l}0.093 * \\
(0.057)\end{array}$ & $\begin{array}{c}-0.004 * * * \\
(0.001)\end{array}$ & $\begin{array}{c}0.089 \\
(0.057)\end{array}$ & $\begin{array}{c}-0.006^{* * * *} \\
(0.001)\end{array}$ & $\begin{array}{l}0.096^{*} \\
(0.055)\end{array}$ & $\begin{array}{c}-0.005^{* * * *} \\
(0.001)\end{array}$ & $\begin{array}{c}0.123 * * \\
(0.063)\end{array}$ & $\begin{array}{c}-0.005 * * * \\
(0.001)\end{array}$ & $\begin{array}{c}0.135^{* *} \\
(0.065)\end{array}$ \\
\hline INSTHOLD & $\begin{array}{c}-0.021^{* * * *} \\
(0.004)\end{array}$ & & $\begin{array}{c}-0.024 * * * \\
(0.004)\end{array}$ & & $\begin{array}{c}-0.019 * * * \\
(0.004)\end{array}$ & & $\begin{array}{c}-0.029 * * * \\
(0.004)\end{array}$ & & $\begin{array}{c}-0.026^{* * * *} \\
(0.004)\end{array}$ & \\
\hline LNNUMBH & & $\begin{array}{l}-0.010 \\
(0.057)\end{array}$ & & $\begin{array}{l}-0.025 \\
(0.056)\end{array}$ & & $\begin{array}{c}0.007 \\
(0.055)\end{array}$ & & $\begin{array}{c}0.023 \\
(0.062)\end{array}$ & & $\begin{array}{c}0.019 \\
(0.065)\end{array}$ \\
\hline LNFMAGE & $\begin{array}{c}-0.008 * * * \\
(0.001)\end{array}$ & & $\begin{array}{c}-0.008 * * * \\
(0.001)\end{array}$ & & $\begin{array}{c}-0.008 * * * \\
(0.001)\end{array}$ & & $\begin{array}{c}-0.008^{* * * *} \\
(0.001)\end{array}$ & & $\begin{array}{c}-0.008^{* * * *} \\
(0.001)\end{array}$ & \\
\hline LNCEOAGE & & $\begin{array}{c}1.430 * * * \\
(0.212)\end{array}$ & & $\begin{array}{c}0.813 * * * \\
(0.201)\end{array}$ & & $\begin{array}{c}0.866 \text { *** } \\
(0.191)\end{array}$ & & $\begin{array}{c}0.668^{* * *} * \\
(0.216)\end{array}$ & & $\begin{array}{c}1.528 * * * \\
(0.245)\end{array}$ \\
\hline LNTEN & & $\begin{array}{c}-0.615 * * * \\
(0.039)\end{array}$ & & & & & & & & $\begin{array}{c}-0.606^{* * *} \\
(0.045)\end{array}$ \\
\hline CEOSH & & & & $\begin{array}{c}-3.107 * * * \\
(0.709)\end{array}$ & & & & & & $\begin{array}{c}-0.422 \\
(0.708)\end{array}$ \\
\hline DUAL & & & & & & $\begin{array}{c}-0.316^{* * * *} \\
(0.052)\end{array}$ & & & & $\begin{array}{l}-0.062 \\
(0.064)\end{array}$ \\
\hline POD & & & & & & & & $\begin{array}{c}1.148^{* * *} \\
(0.266)\end{array}$ & & $\begin{array}{c}0.714 * * \\
(0.284)\end{array}$ \\
\hline INDUSTRY & Yes & Yes & Yes & Yes & Yes & Yes & Yes & Yes & Yes & Yes \\
\hline YEAR & Yes & Yes & Yes & Yes & Yes & Yes & Yes & Yes & Yes & Yes \\
\hline Sample Size & 16,726 & 16,726 & 16,726 & 16,726 & 16,726 & 16,726 & 14,504 & 14,504 & 14,504 & 14,504 \\
\hline
\end{tabular}




\section{Table 9. Summary Statistics and Correlations}

The variable DSOX is a dummy variable that is equal to one if (fiscal) year is during the period of 2003 to 2006, and to zero otherwise. The four entrenchment proxies are defined as in Table 1. The sample period is 1995-2005 (the observations for year 2006 are dropped due to the insufficient observations for FORCETURN). Panel A reports the summary statistics of the four entrenchment proxies for the pre-SOX period (DSOX $=0$ ) and the post-SOX period (DSOX=1). Panel B presents the pairwise correlations of the five variables with $p$-values reported in parentheses.

Panel A. Summary Statistics

\begin{tabular}{l|cccccc}
\hline & Nobs & Mean & Std. Dev. & Min & Max & Median \\
\hline DSOX=0 & & & & & & \\
LNTEN & 11,449 & 2.004 & 0.771 & 0 & 4.111 & 1.946 \\
SHROWNPC & 11,449 & 0.029 & 0.067 & 0 & 0.642 & 0.004 \\
CEOCHAIR & 11,449 & 0.679 & 0.467 & 0 & 1 & 1 \\
PODN & 9,547 & 0.773 & 0.128 & 0 & 1 & 0.8 \\
& & & & & & \\
DSOX=1 & & & & & & \\
LNTEN & 4,269 & 1.873 & 0.751 & 0 & 4.025 & 1.792 \\
SHROWNPC & 4,269 & 0.020 & 0.055 & 0 & 0.583 & 0.003 \\
CEOCHAIR & 4,269 & 0.601 & 0.490 & 0 & 1 & 1 \\
PODN & 3,982 & 0.819 & 0.097 & 0 & 1 & 0.857 \\
\hline
\end{tabular}

Panel B. Pairwise Correlations

\begin{tabular}{l|ccccc}
\hline & DSOX & LNTEN & SHROWNPC & CEOCHAIR & PODN \\
\hline DSOX & 1.0000 & & & & \\
LNTEN & -0.0759 & 1.0000 & & & \\
& $(0.000)$ & & & & \\
SHROWNPC & -0.0643 & 0.3498 & 1.0000 & & \\
& $(0.000)$ & $(0.000)$ & & & \\
CEOCHAIR & -0.0732 & 0.2952 & 0.1191 & 1.0000 & \\
& $(0.000)$ & $(0.000)$ & $(0.000)$ & & \\
PODN & 0.1733 & -0.2218 & -0.3076 & 0.0477 & 1.0000 \\
& $(0.000)$ & $(0.000)$ & $(0.000)$ & $(0.000)$ & \\
\hline
\end{tabular}


Table 10. Estimation of the Reduced-Form FORCETURN Equation and PIN Equation

This table reports the estimation results on the reduced-form FORCETURN equation (in the left half) and the reduced-form PIN equation (in the right half) using data over 1995-2005. We fit a maximumlikelihood probit model on the FORCETURN equation, and we estimate the PIN equation with the OLS regression method. Firms are classified into one of the Fama-French 49 industries. Estimates on the industry dummies and year dummies are suppressed to save space. Robust standard errors adjusted for clustering in firms are reported in parentheses. $*, * *$, and $* * *$ denote (two-sided) significance at the $10 \%, 5 \%$, and $1 \%$ levels, respectively.

\begin{tabular}{|c|c|c|c|c|}
\hline & FORCETURN & FORCETURN & PIN & PIN \\
\hline INTERCEPT & $\begin{array}{c}-4.219 * * * \\
(0.814)\end{array}$ & $\begin{array}{c}-4.300 * * * \\
(0.809)\end{array}$ & $\begin{array}{c}0.337 * * * \\
(0.027)\end{array}$ & $\begin{array}{c}0.344 * * * \\
(0.027)\end{array}$ \\
\hline LNME & $\begin{array}{l}-0.026 \\
(0.029)\end{array}$ & $\begin{array}{c}-0.023 \\
(0.028)\end{array}$ & $\begin{array}{c}-0.015^{* * *} * \\
(0.001)\end{array}$ & $\begin{array}{c}-0.016 * * * \\
(0.001)\end{array}$ \\
\hline ROA & $\begin{array}{c}-0.746^{* * *} \\
(0.153)\end{array}$ & $\begin{array}{c}-0.756^{* * *} * \\
(0.154)\end{array}$ & $\begin{array}{c}0.013 \\
(0.011)\end{array}$ & $\begin{array}{c}0.016 \\
(0.011)\end{array}$ \\
\hline RET1YR & $\begin{array}{c}-0.769 * * * \\
(0.118)\end{array}$ & $\begin{array}{c}-0.755^{* * *} * \\
(0.113)\end{array}$ & $\begin{array}{c}0.004 * * \\
(0.002)\end{array}$ & $\begin{array}{c}0.005 * * * \\
(0.002)\end{array}$ \\
\hline INDRET & $\begin{array}{c}0.364 * * * \\
(0.085)\end{array}$ & $\begin{array}{c}0.313 * * * \\
(0.076)\end{array}$ & $\begin{array}{c}-0.013 * * * \\
(0.002)\end{array}$ & $\begin{array}{c}-0.010 * * * \\
(0.003)\end{array}$ \\
\hline BETA & $\begin{array}{c}-0.012 \\
(0.044)\end{array}$ & $\begin{array}{l}-0.033 \\
(0.040)\end{array}$ & $\begin{array}{c}-2.00 \mathrm{e}-4 \\
(0.002)\end{array}$ & $\begin{array}{c}0.005 * * * \\
(0.002)\end{array}$ \\
\hline VOL1YR & $\begin{array}{l}-0.200 \\
(0.181)\end{array}$ & $\begin{array}{l}-0.099 \\
(0.148)\end{array}$ & $\begin{array}{c}0.026 * * * \\
(0.008)\end{array}$ & $\begin{array}{c}0.005 \\
(0.010)\end{array}$ \\
\hline LNSHTURN & $\begin{array}{c}0.214 * * * \\
(0.041)\end{array}$ & $\begin{array}{c}0.219 * * * \\
(0.041)\end{array}$ & $\begin{array}{c}-0.011 * * * \\
(0.002)\end{array}$ & $\begin{array}{c}-0.012 * * * \\
(0.002)\end{array}$ \\
\hline TOBIN & $\begin{array}{l}-0.031 \\
(0.022)\end{array}$ & $\begin{array}{c}-0.033 \\
(0.022)\end{array}$ & $\begin{array}{c}0.004 * * * \\
(0.001)\end{array}$ & $\begin{array}{c}0.003 * * * \\
(0.001)\end{array}$ \\
\hline LNNUMEST & $\begin{array}{l}0.099 * \\
(0.057)\end{array}$ & $\begin{array}{l}0.098^{*} \\
(0.057)\end{array}$ & $\begin{array}{c}-0.007 * * * \\
(0.002)\end{array}$ & $\begin{array}{c}-0.006 * * \\
(0.002)\end{array}$ \\
\hline INSTHOLD & $\begin{array}{c}-0.881^{* * *} * \\
(0.197)\end{array}$ & $\begin{array}{c}-0.858 * * * \\
(0.193)\end{array}$ & $\begin{array}{c}-0.033 * * * \\
(0.007)\end{array}$ & $\begin{array}{c}-0.038 * * * \\
(0.007)\end{array}$ \\
\hline LNNUMBH & $\begin{array}{c}0.194 * * * \\
(0.066)\end{array}$ & $\begin{array}{c}0.193 * * * \\
(0.066)\end{array}$ & $\begin{array}{c}0.008 * * * \\
(0.002)\end{array}$ & $\begin{array}{c}0.007 * * * \\
(0.002)\end{array}$ \\
\hline LNFMAGE & $\begin{array}{c}-0.005 \\
(0.038)\end{array}$ & $\begin{array}{c}0.001 \\
(0.038)\end{array}$ & $\begin{array}{c}-0.008 * * * \\
(0.001)\end{array}$ & $\begin{array}{c}-0.008 * * * \\
(0.001)\end{array}$ \\
\hline LNCEOAGE & $\begin{array}{c}0.597 * * * \\
(0.191)\end{array}$ & $\begin{array}{c}0.621 * * * \\
(0.191)\end{array}$ & $\begin{array}{l}-0.005 \\
(0.006)\end{array}$ & $\begin{array}{c}-0.008 \\
(0.006)\end{array}$ \\
\hline DSOX & $\begin{array}{c}\text { 0.216** } \\
(0.110)\end{array}$ & $\begin{array}{c}\text { 0.129** } \\
(\mathbf{0 . 0 5 8 )}\end{array}$ & $\begin{array}{c}-0.029 * * * * \\
(0.002)\end{array}$ & $\begin{array}{c}-0.006 * * * * \\
(0.002)\end{array}$ \\
\hline $\begin{array}{l}\text { YEAR } \\
\text { (1996-2002) } \\
\text { INDUSTRY }\end{array}$ & $\begin{array}{l}\text { Yes } \\
\text { Yes }\end{array}$ & $\begin{array}{l}\text { No } \\
\text { Yes }\end{array}$ & $\begin{array}{l}\text { Yes } \\
\text { Yes }\end{array}$ & $\begin{array}{l}\text { No } \\
\text { Yes }\end{array}$ \\
\hline $\begin{array}{l}\text { Sample Size } \\
\mathrm{R}^{2}\end{array}$ & 15,718 & 15,718 & $\begin{array}{c}15,718 \\
0.294\end{array}$ & $\begin{array}{c}15,718 \\
0.276\end{array}$ \\
\hline
\end{tabular}




\section{Table 11. Estimation of the Structural System: the PIN Equation}

This table reports the maximum likelihood estimates on the PIN equation in the structural system. The dependent variable of interest is PIN, and the endogenous variable on the right hand-side of this equation is FORCETURN. The FORCETURN relation follows a reduced-form probit model specification:

$\operatorname{Prob}($ FORCETURN $)=\lambda_{0}+\lambda_{1} * L N M E+\lambda_{2} * R O A+\lambda_{3} * R E T 1 Y R+\lambda_{4} * I N D R E T+\lambda_{5} * B E T A$

$+\lambda_{6} *$ VOLIYR $+\lambda_{7} *$ LNSHTURN $+\lambda_{8} *$ TOBIN $+\lambda_{9}{ }^{*}$ LNNUMEST $+\lambda_{10} *$ INSTOHOLD

$+\lambda_{11} * L N N U M B H+\lambda_{12} *$ LNFMAGE $+\lambda_{13} *$ LNCEOAGE $+\lambda_{14} * D S O X+$ INDUSTRY/YEAR,

where $D S O X$ is a dummy variable that equals one for years 2003-2005 and zero otherwise. Estimation results on the FORCETURN relation are suppressed for brevity. The sample period is 1995-2005. Firms are classified into one of the Fama-French 49 industries. Estimates on the industry dummies and year dummies are not reported. Robust standard errors adjusted for clustering in firms are reported in parentheses. $*, * *$, and $* * *$ denote (two-sided) significance at the $10 \%, 5 \%$, and $1 \%$ levels, respectively.

\begin{tabular}{|c|c|c|}
\hline & Model (1) & Model (2) \\
\hline INTERCEPT & $\begin{array}{c}0.315 * * * \\
(0.010)\end{array}$ & $\begin{array}{c}0.312 * * * \\
(0.011)\end{array}$ \\
\hline FORCETURN & $\begin{array}{c}-0.009 * * \\
(0.004)\end{array}$ & $\begin{array}{c}-0.010 * * \\
(0.004)\end{array}$ \\
\hline LNME & $\begin{array}{c}-0.015 * * * \\
(0.001)\end{array}$ & $\begin{array}{c}-0.017 * * * \\
(0.002)\end{array}$ \\
\hline ROA & $\begin{array}{c}0.012 \\
(0.011)\end{array}$ & $\begin{array}{c}0.014 \\
(0.011)\end{array}$ \\
\hline RET1YR & $\begin{array}{c}0.002 \\
(0.002)\end{array}$ & $\begin{array}{c}0.003 \\
(0.002)\end{array}$ \\
\hline BETA & $\begin{array}{l}1.01 \mathrm{e}-4 \\
(0.002)\end{array}$ & $\begin{array}{c}0.005^{* * * *} \\
(0.001)\end{array}$ \\
\hline VOL1YR & $\begin{array}{c}0.028 * * * \\
(0.008)\end{array}$ & $\begin{array}{c}0.009 \\
(0.009)\end{array}$ \\
\hline LNSHTURN & $\begin{array}{c}-0.011 * * * \\
(0.002)\end{array}$ & $\begin{array}{c}-0.012 * * * \\
(0.002)\end{array}$ \\
\hline TOBIN & $\begin{array}{c}0.003 * * * \\
(0.001)\end{array}$ & $\begin{array}{c}0.003 * * * \\
(0.001)\end{array}$ \\
\hline LNNUMEST & $\begin{array}{c}-0.008 * * * \\
(0.002)\end{array}$ & $\begin{array}{c}-0.007 * * * \\
(0.002)\end{array}$ \\
\hline INSTHOLD & $\begin{array}{c}-0.019 * * * \\
(0.007)\end{array}$ & $\begin{array}{c}-0.024 * * * \\
(0.006)\end{array}$ \\
\hline LNFMAGE & $\begin{array}{c}-0.008^{* * *} \\
(0.001)\end{array}$ & $\begin{array}{c}-0.009 * * * \\
(0.001)\end{array}$ \\
\hline DSOX & $\begin{array}{c}-0.028 * * * \\
(0.002)\end{array}$ & $\begin{array}{c}-0.007 * * * \\
(0.002)\end{array}$ \\
\hline $\begin{array}{l}\text { YEAR } \\
\text { (1996-2002) } \\
\text { INDUSTRY }\end{array}$ & $\begin{array}{l}\text { Yes } \\
\text { Yes }\end{array}$ & $\begin{array}{l}\text { No } \\
\text { Yes }\end{array}$ \\
\hline Sample Size & 15,718 & 15,718 \\
\hline Loglikelihood & $20,409.63$ & $20,234.00$ \\
\hline
\end{tabular}

